See discussions, stats, and author profiles for this publication at: https://www.researchgate.net/publication/332739515

\title{
Duyusal İşlemleme Hassasiyeti: Kuramsal Çerçeve ve Derleme Çalışması
}

Article · December 2018

DOI: $10.31828 /$ tpy.13019961.2018.42.02.03

CITATIONS

2 authors:

Gulbin Sengul Inal

Middle East Technical University

4 PUBLICATIONS 4 CITATIONS

SEE PROFILE
Nebi Sümer

Middle East Technical University

102 PUBLICATIONS 2,895 CITATIONS

SEE PROFILE

Some of the authors of this publication are also working on these related projects:

Early Parenting Support: Application of an Video Feedback Intervention Program to Enhance Maternal Sensitivity and Secure Attachment View project

Checklist of metazoon parasites recorded in Anura and Urodela from Turkey View project 


\title{
Duyusal İşlemleme Hassasiyeti: Kuramsal Çerçeve ve Derleme Çalışması
}

\author{
Gülbin Şengül-İnal \\ Orta Doğu Teknik Üniversitesi
}

\author{
Nebi Sümer
}

Sabancı Üniversitesi

\begin{abstract}
Özet
Bu çalışmanın amacı Aron ve Aron (1997) tarafından geliştirilen ve son yıllarda özellikle kişilik psikolojisi alanında yaygın olarak çalışılan Duyusal İşlemleme Hassasiyeti (DİH; sensory processing sensitivity) üzerine yapılan çalışmaları derlemektir.DİH iç veya dış kaynaklı uyarıcılara karşı aşırı hassas olma durumu olarak tanımlanan kalıtımsal bir yetişkin mizaç özelliğidir. Bu yazıda DİH üzerine yapılmış geçmiş çalışmalar sistematik olarak taranmış ve altı alt bölümde derlenen 35 görgül çalışma ışığında konu detaylı olarak ele alınmıştır. Yapılan çalışmalarda DİH'in biyolojik altyapıya dayandığı ve utangaçlık, içekapanıklılık ve negatif duygulanım gibi kişilik özellikleriyle yakın ilişkili olduğu görülmüştür. DİH'in stres ve depresyon gibi olumsuz psikolojik değişkenlerle ilişkili bulunması aşırı hassas kişiler için dezavantaj olarak görülse de dış ve iç kaynaklı uyaranlara karşı hızlı farkındalık ve tepkisellik bu kişilik özelliğinin işlevsel yönünü ortaya koymaktadır. Alt başlıklarda özetlenen temel bulgular DİH'in kişilik özelliklerinden olumsuz psikolojik sonuçlara kadar birçok alanda önemli doğurguları olduğunu göstermektedir. Bu kapsamda ilgili kültürel faktörler ve gelecek çalışmalara ilişkin öneriler de tartışılmıştır.
\end{abstract}

Anahtar kelimeler: Duyusal işlemleme hassasiyeti, aşırı hassas kişiler, yetişkin mizacı, kişilik

\begin{abstract}
This paper aims to systematicallyreview the current literature on sensory processing sensitivity (SPS), proposed by Aron and Aron (1997), and that has recently beenincreasingly investigated especially within personality psychology. SPS is a genetically disposed adult temperament trait, which is described as being highly sensitive to internal and external stimulations. In the current review, previous studies on SPS have been thoroughly elaborated with a total of 35 empirical studies in six sub-areas. Reviewed studies have shown that SPS has a biological underpinning and is closely associated with certain personality traits, such as shyness, introversion, and negative affectivity. On the one hand, those with high levels of SPS have a tendency for having negative psychological outcomes, such as stress proneness and depression, which can be seen as a disadvantage. On the other hand, they have rapid awareness and keen reactivity to both external and internal stimuli, which can be considered as a functional aspect of this trait. Overall, findings have demonstrated that SPS has critical implications for a number of personality traits as well as positive and negative psychological outcomes. These implications were discussed considering the potential cultural factors and directions for future research.
\end{abstract}

Key words: Sensory processing sensitivity, highly sensitive people, adult temperament, personality

Yazışma Adresi: Arş. Gör. Gülbin Şengül-İnal, Orta Doğu Teknik Üniversitesi, Fen-Edebiyat Fakültesi, Psikoloji Bölümü, Üniversiteler Mah. Dumlupınar Blv. No:1, Çankaya / Ankara

E-posta: gulbinsengul@gmail.com

Gönderim Tarihi: 01.04.2017

Kabul Tarihi: 25.10.2018 
İnsanlar sosyal ve fiziksel çevrelerindeki uyaranları algılar, yorumlar, organize eder ve bu uyaranlara uygun tepkiler geliştirirler. İnsanların sosyal ve fiziksel çevrelerindeki her türlü uyaran merkezi sinir sistemi aracılığıyla duyusal işlemleme sürecinden geçer. $\mathrm{Bu} \mathrm{du-}$ yusal işlemleme süreci insanların bilinçli farkındalıkları olmadan yaşadıkları nörolojik ve döngüsel bir süreçtir (May, 2007). Bu döngünün ilk aşamasında, çevreden gelen uyarıcı, ilgili duyu organının reseptörleri aracılığıyla beynimize iletilir. İkinci aşamada, iletilen bilgiyi algıya çeviren beynimiz uyaranın türü ve şiddeti gibi özelliklerini analiz eder ve bağlantılar kurar. Son aşamada beynimiz tarafindan algılanan ve yorumlanan uyarıcıya karşı davranışsal veya duygusal tepki oluşturulur. Bu aşamada uyaranın ne olduğuna bağlı olarak kişi tarafindan tepki geliştirilebilir ya da geliştirilmeyebilir. Ortaya çıkan tepki, duyusal uyarıcı olarak yeniden döngüye girer ve işlemleme süreci tekrar başlar. Duyusal işlemleme sürecini farklı deneyimleyen kişiler duyusal uyaranları fark etme, algılama ve tepki verme durumlarında da anlamlı olarak birbirlerinden farklılaşırlar. Bu bağlamda, kişilerarası bu farklılık, yaşam etkinliklerimizi, ilgi alanlarımızı, çevreyle uyumumuzu, duygusal ve davranışsal tepkilerimizi şekillendirerek kişilik ve mizaç özelliklerimizin oluşmasinda temel rol oynayan önemli bir faktör haline gelir (Dunn, 1997, 2001; Rothbart ve Jones, 1999). Son y1llarda özellikle duyusal bilgi işleme sürecindeki bireysel farkl1lıklar derinlemesine incelenmiştir.

Duyusal işlemleme sürecindeki bireysel farkl1lıklara olan artan ilgiyi dikkate alarak bu derleme çalışmasında, psikoloji alanında son yıllarda yaygın bir şekilde araştırılan ve duyusal işlemlemeyle ilintili temel bir bireysel farklılık olarak ele alınan duyusal işlemleme hassasiyeti (DİH; sensory processing sensitivity; Aron ve Aron, 1997) derinlemesine irdelenmiştir. Türkçe yazında DİH ile ilgili yeterli çalışma bulunmadığından bu çalışmada DİH'in tanımının yapılması, kuramsal çerçevesinin anlatılması ve DİH üzerine yapılan çalışmaların gözden geçirilmesi amaçlanmaktadır. DİH konusundaki araştırmalar geniş bir yelpazeye yayılması nedeniyle geçmiş araştırma bulgularının sistematik olarak derlenmesi ve doğurgularının yorumlanması DİH yazınına katkıda bulunacaktır. Aşağıdaki ilk bölümde DİH'in kavramsal olarak tanımı yapılmıştır. İkinci bölümde yüksek düzeyde DİH'e sahip kişilerin yaygın görülen özellikleri anlatılmıştır. Üçüncü bölümde DİH'in psikometrik ölçümü için geliştirilen Duyusal İşlemleme Hassasiyeti Ölçeği (DİHÖ; Aron ve Aron, 1997) tanıtılmış ve ölçeğin faktör yapısını inceleyen çalışmalar detaylı incelenmiştir. Dördüncü bölümde DİH üzerine yapılan görgül araştırmalar belli ölçütler doğrultusunda taranmış ve ilgili çalışmaların temel bulguları altı başlık altında özetlenmiştir.

\section{Duyusal İşlemleme Hassasiyeti’nin Tanımlanması}

DİH, Aron ve Aron (1997) tarafindan çok sayıda niteliksel ve niceliksel araştırma bulguları 1şığında geliştirilen, temel olarak kişilerin sosyal ve fiziksel çevrelerindeki içsel (örn., açlık, acı, ağrı gibi) veya dışsal (örn., yüksek ses, parlak 1şık, keskin koku gibi) kaynaklı uyaranları algılama, yorumlama ve bunlara tepki verme yetilerindeki hassasiyet olarak tanımlanan kalıtımsal bir mizaç özelliğidir. Uyaranı algılamadaki bu hassas bilişsel işlemleme süreci temelde davranışsal ve duygusal tepkiselliğe dayalıdır (Aron, Aron ve Jagiellowicz, 2012).

DİH'in kuramsal çerçevesini temel olarak hayvan türlerindeki mizaç özellikleri oluşturmaktadır. Buna göre, hayvanlar doğaya ayak uydurmak ve hayatta kalabilmek için belirli mizaç türleri geliştirmişlerdir. $\mathrm{Bu}$ mizaç türleri hayvanların yaşadıkları çevreye ve hayatta kalma stratejilerine göre şekillenmektedir. Örneğin, zorlu yaşam şartlarında yetişen bir hayvan türü daha saldırgan ve cesur olurken, tehlike ve tehdidin olmadığ 1 bir ortamda yetişen bir hayvan türü daha ürkek ve dikkatli davranabilmektedir (Wilson, Clark, Coleman ve Dearstyne, 1994). Bu davranış biçimleri temel düzeyde yaklaşma ve kaçınma davranışı olmak üzere ikiye ayrılmaktadır. Çevresel uyaran tepkiselliğinin arttığı durumlarda kaçınma davranışı sergilenmekte, bu tepkiselliğe sahip olmayan hayvan türlerinde ise yaklaşma davranışı gözlemlenmektedir. Karşılaşılan yeni durum ve ortamlara daha yavaş tepki verilmesi, dürtüselliğin düşük olması ve risk alma konusunda daha çekingen davranılması çevresel uyaran tepkiselliğinin davranışsal yansımalar1 olarak görülebilir. Sonuç olarak, bu tepkisellik bazı türlerin yeni ve tehlikeli ortamlarda daha saldırgan ve cesur davranmalarına (baskın tür), diğer türlerin ise bu gibi ortamlarda daha dikkatli ve ürkek davranmalarına (çekingen tür) yol açmaktadır.

Hayvan türlerinde gözlemlenen bu davranış biçimlerinin insanlardaki yansıması DİH olarak kabul edilmektedir. Psikoloji yazınında benzer tepkisellik ve dürtüsellik davranışları önceki çalışmalarda utangaçlık (Cheek ve Buss, 1981), içe kapanıklık (Eysenck, 1991), davranışsal inhibisyon (Kagan, 1994) ya da fizyolojik tepkisellik (Strelau, 1983) gibi kavramlar altında incelenmiştir. Bu kişilik özellikleri her ne kadar farklı isimlerle tanımlanmış olsa da, insanların çevresel uyaranlara karşı verdikleri tepkisellik durumu kuramsal olarak aynı çerçevede yer almaktadır ve bunlar DİH kuramı altında toplanmıştır.

Toplumdaki bireylerin aşırı hassas olanlar ve olmayanlar olmak üzere iki kategoriye ayrıldığı (Borries, 2012) ve görece yüksek DİH'e sahip bireylerin toplumun yaklaşık \%20'sini oluşturduğu görülmüştür (Aron 
ve Aron, 1997). Toplumdaki azınlık grubun sahip olduğu bu mizaç özelliği genellikle duyusal işlemleme bozukluğu ile karıştırılabilmektedir (Aron, 2011). Duyusal işlemleme bozukluğu duyu organlarımız ile algıladığımız uyaranları algılama, ayırt etme ve düzenleme işlemlerindeki yetersizlik olarak tanımlanan nörolojik bozukluktur. Ancak DİH, merkezi sinir sisteminin yanlış ya da yetersiz çalışması ya da duyu organlarının daha işlevsel olmasından değil, bilişsel süreçlerin bilinenden daha hassas çalışmasından kaynaklanmaktadır. DİH'in daha iyi tanımlanması ve diğer mizaç özelliklerinden ve birtakım bilişsel bozukluklardan ayırt edilebilmesi için dört temel özelliğine vurgu yapılmıștır (Aron, 2011; Aron ve ark., 2012). Bunlar (1) işlemleme sürecinin derinliği, (2) davranışın inhibisyonu, (3) uyarıcı hassasiyeti ve (4) duygusal/fizyolojik tepkiselliktir.

(1) İşlemleme sürecinin derinliği. Derin bilişsel işlemleme, duyusal hassasiyeti olan insanlarda görünen en temel özelliklerden biridir. Derin bilişsel işlemleme süreci yaşayan aşırı hassas kişiler hassas olmayan kişilere kıyasla fark etmesi zor bir değişiklik ile karşılaştıklarında daha dikkatli davranır ve değişikliğin niteliği ile ilgili daha kesin ve doğru tahminlerde bulunurlar. Karmaşık durum ve olaylarla karşı karşıya kaldıklarında ya da aynı anda birden fazla görevi yerine getirmeleri gerektiğinde bilişsel yükleri artar. Bu durumda aşırı hassas kişilerin gerginlik ve stres düzeylerinde gözle görülür bir artış olur. Bu bağlamda bilişsel işlemleme sürecinin hassas olması içsel ve dışsal kaynaklı uyaranların daha ayrıntıl1 ve hassasiyetle algılanması ve işlenmesi demektir. Bu durum aşırı hassas çalışma prensiplerine sahip bir sinir sisiteminin ve buna bağlı olarak gözlemlenen yoğun bilişsel süreçlerin bir ürünü olarak karşımıza çıkmaktadır.

(2) Davranışın inhibisyonu. Davranışın inhibisyonu temel olarak Gray $(1981,1991)$ tarafindan ortaya atılan ve Eysenck'in (1967) sunduğu iki uçlu (dıșadönüklük-İçedönüklük ve nörotisizm-dengelilik) kişilik teorisinden anlamlı olarak farklılaşan bir biyopsikolojik kişilik kuramıdır. Eysenck'in kişilik kuramında içedönüklük-dışadönüklük kişilik yapıları sosyalliği ve dürtüselliği temsil ederken, nörotisizm-dengelilik boyutları ise kaygıyı, aşırı tepkiselliği, duygusal yoğunluğu ve değişkenliği temsil etmektedir. Gray, Eysenck’ten farklı olarak ödüllendirme ve cezalandırma mekanizmalarının çalışma ilkelerine vurgu yaparak kişilik boyutlarının temel olarak ödüle ve cezaya karşı verilen tepkiler noktasında ayrıştığını öne sürmektedir. Gray'in sunduğu iki faktörlü kişilik kuramı davranışsal inhibisyon sistemi (DİS) ve davranışsal aktivasyon sistemi (DAS) olmak üzere ikiye ayrılır. DİS ceza durumlarında gösterilen kaçınma motivasyonu olarak tanımlanırken, DAS ise ödül durumlarında yaklaşma motivasyonu olarak tanımlanmaktadır. Buna göre, DİS hassasiyeti kaygı, korku, içedönüklük ve duygusallık (Aron ve Aron, 1997; Smolewska, McCabe ve Woody, 2006), DAS hassasiyeti ise dürtüsellik, dışadönüklük ve heyecan arama ile ilişkilidir (Gray, 1990).

DİS uyarıcı sistemi aktive edildiğinde kaçınma motivasyonunu tetikleyerek kişilerin olaylar ve durumlar karşısında duraksama ve kontrol etme ihtiyacını ortaya çıkarmaktadır. Bu kaçınma davranışı kişilerin daha derin ve ayrıntılı bilişsel süreçler yaşamalarına sebep olmaktadır. Dolayısıyla yüksek düzeyde DİS hassasiyetine sahip olan kişilerin aynı zamanda çevresel uyaranlara karşı da hassasiyet geliştirmeleri olağandır. DİS hassasiyetinin neden olduğu algılaması güç uyarıcıları algılama yetisi, aşırı duygusal tepkisellik ve bu tepkisellikten dolayı geliştirilen kaçınmacı motivasyonu genellikle DİH'in kavramsal ve kuramsal çerçevesi ile birebir uyuşmaktadır (Bkz., Aron ve ark., 2012). Fakat bu konu üzerine yapılan tartışmalar ve görgül araştırmalar DİS'in DİH'i tam olarak açıklayamadığını fakat DİH'in DİS'i kapsayıcı nitelikte olduğunu göstermektedir (Smolewska ve ark., 2006).

(3) Uyarıcı hassasiyeti. Uyarıcı hassasiyeti kişilerin açlık, ağrı, acı gibi içsel ya da 1şık, koku, ses gibi dışsal kaynaklı uyarıcılara karşı aşırı hassas ve tepkisel olma durumudur. Mizaç yazınına bakıldığında birçok mizaç özelliğinin tanımlanması ve kavramsallaştırılmasında uyarıcı hassasiyetinin temel alındığı görülmektedir. Örneğin, uyarıcı hassasiyeti Thomas ve Chess'in (1977) önerdiği dokuz mizaç özelliğinden eşik düzeyi tepkisi ile aynı anlama gelirken, aynı özellik Strela ve Zawadzki'nin (1993) mizaç özellikleri çalışmasında duyusal hassasiyet olarak karşımıza çıkmaktadır. Uyarıcı hassasiyetinin birçok mizaç kuramının ortak noktası olması, bu özelliğin DİH için de önemini ortaya koymaktadir.

Uyarıcı hassasiyetinde uyarıcının şiddeti aşırı hassas kişiler için kritik bir etken değildir. Bunun en önemli sebebi aşırı hassas kişilerin duyusal eşik düzeylerinin düşük olmasıdır. Bu nedenle aşırı hassas kişiler uyarıcılardan normal şiddet ve sürenin üstünde etkilenirler. $\mathrm{Bu}$ görüşü destekler şekilde Wachs'in (2013) anneler üzerinde yaptığı bir çalışmada aşırı hassas annelerin diğer annelere oranla ev ortamını daha kaotik ve karmaşık algıladıkları bulunmuştur. Aşırı uyarılma sonucu ortaya çıkan uyarıcı hassasiyeti sadece içsel ya da dişsal uyaranlara karşı değil, üzüntü, kaygı, neşe gibi duygu durumlarına karşı da geliştirilebilir. Üzüntü verici ya da kaygı yaratan bir durum ile karşılaşmak da aşırı uyarılma yarattığından dolayı aşırı hassas kişiler bu duygu durumlarına da hassasiyet göstererek bu duygu durumlarını uç noktalarda deneyimleyebilirler.

Sürekli ve şiddetli uyarıcılara maruz kalınması hassas kişilik özellliğinden bağımsız olarak insanların 
bilişsel yüklerini arttırarak günlük aktiviteleri zorlayan bir durum haline gelebilir. Oluşan bu bilişsel yükün asgari düzeye indirilmesine yardımcı olan uyarıcıya alışma (habituation) ve uyarıcıya duyarlılaşma (sensitization) olmak üzere iki önemli biyolojik strateji bulunmaktadır. Uyarıcıya alışma uzun süredir devam eden ya da sık sık tekrarlanan uyarıcılara karşı verilen tepkilerin azalmas1 olarak tanımlanırken (örn., Thompson ve Spencer, 1966), uyarıcıya duyarlılaşma ise uyarıcılara karşı verilen tepkilerin artması olarak tanımlanmaktadır (örn., Groves ve Thompson, 1970).

Uyarıcıya alışma ve duyarlılaşma süreçleri aşır1 hassas kişilerde farklı örüntüler gösterebilmektedir. Örneğin, değiş̧en cilt iletkenlik düzeylerinin dört duyu işlemleme tipi ile karakterize olmuş yetişkin duyu profillerine göre nasıl değișkenlik gösterdiğini inceleyen Brown, Tollefson, Dunn, Cromwell ve Filion (2001), düşük duyusal eşiğin bir ürünü olarak ortaya çıkan $d u$ yusal hassasiyet profiline sahip kişilerin bu profile sahip olmayan kişilere kıyasla uyarıcıya alışma sürelerinin daha uzun olduğunu gözlemlemişlerdir. Bu bağlamda, aşırı hassas kişilerin uyarıcıya alıșma sürelerinin daha uzun fakat uyarıcıya duyarlılaşma sürelerinin daha kısa olduğu söylenebilir.

(4) Duygusal/fizyolojik tepkisellik. Duygusal tepkisellik insanların sosyal ilişkilerinde sık sık ve yoğun bir şekilde duygusal uyarılma yaşamalarıdır. Bu duygusal uyarılmalar neşe, korku ve öfke gibi duyguların kişi tarafindan yoğun bir şekilde hissedilmesine ve kişinin duygusal tepkilerin ön plana çıkmasına neden olmaktadır. Duygusal tepkiselliğin en önemli belirleyicisi duygusal deneyimlerin yoğunluğu ve uyarımları algılamadaki duyusal eşik düzeyidir. Bu anlamda duygusal tepkiselliğe sahip kişilerin duyusal eşik düzeylerinin düşük olmasından dolayı duygu yüklü deneyimleri diğer kişilere göre daha yoğun ve derin yaşarlar. Bu durumun aşırı hassas kişilerde oluşturduğu en büyük zorluk olay ve durumlar karşısında uygun davranış ve tepki geliştirme güçlüğüdür. Duygusal olarak uyarılan aşırı hassas kişiler her ne kadar durum ve olayları hızlı bir şekilde algılama ve doğru yorumlama becerilerine sahip olsa da duygusal olarak geliştirdikleri ve davranışsal olarak somutlaştırdıkları tepkisel motivasyonları onları aşırı hassas olmayan bireylerden ayıran en karakteristik özelliklerden biridir.

Duygu yüklü deneyimler sadece olumsuz duygu durumlarını değil olumlu duygu durumlarını da kapsamaktadır. Bu duygusal tepkisellik bir süre sonra öğrenilmiş davranış haline gelir ve benzer olay ve durumlarda da aynı tepkisellik gösterilir. Duyusal hassasiyeti olan kişilerin çevresel durum ve olaylara daha hassas cevap verme becerilerinin oluşmasının altında yatan temel sebeplerden biri de önceden öğrenilen duygusal tepkiselliktir. Duygusal tepkisellik tümüyle DİH ile açıklana- mayacağ 1 gibi, DİH de tamamen duygusal tepkisellik ile açıklanamaz (Aron ve ark., 2012). Fakat duygusal tepkisellik, bu mizaç türünün sebep olduğu birçok davranışsal farklılıklara 1şık tutabilecek bir değişkendir.

\section{Aşırı Hassas Kişilerin Özellikleri}

Așırı hassas kișiler çevrelerindeki farketmesi zor detayları ve değişiklikleri daha hızlı farketme, yoğun ve güçlü uyaranlardan (örn., parlak ış1k, güçlü koku, yüksek ses gibi) aşırı rahatsız olma ve duygusal yükü yoğun olumlu veya olumsuz olay ve durumlara karşı aşırı hassasiyet gösterme gibi yaygın davranış örüntüleri gösterirler (Aron ve Aron, 1997; Aron ve ark., 2012). Aşırı hassas kişilerin duyusal algılama eşikleri hassas olmayan kişilere kıyasla daha düşük olduğundan bilgi işlemleme süreçleri daha derinlemesine ve hızlı bir şekilde gerçekleşmektedir. Bu nedenle, şiddeti düşük veya orta düzeyde olan bir uyarıcı bile hassas kişiler tarafından aşırı uyaran olarak algılanabilir.

Aşırı hassas kişiler bir anlamda Gray $(1981,1991)$ tarafindan önerilen DİS hassasiyetine sahip bireylerdir. DİS, kişilerin herhangi bir davranışı sergilemeden önce durup düşünmelerine ve geçmiş yaşantılarını ve deneyimlerini gözden geçirerek olası riskli ve olumsuz durumların oluşmasına izin vermeyecek şekilde davranmalarına neden olmaktadır. DİS hassasiyetinin neden olduğu bu davranış tipine genel olarak 'dur-ve-kontrol et' (pause-to-check) sistemi denmektedir (Aron ve Aron, 1997; Aron ve ark., 2012). Aşırı hassas kişiler daha ayrıntılı ve derin bilişsel işlemleme süreci geçirdiklerinden özellikle yeni bir ortama girdiklerinde ya da belirsiz bir durum ile karşılaştıklarında çevresel uyaranları daha hassasiyetle algılar ve yorumlarlar. Bu durum aşırı hassas kişilerin hassas olmayan kişilere kıyasla çevresel uyaranları algılamak için ihtiyaçları olan sürenin daha uzun olmasına neden olmaktadır. Aşırı hassas kişilerin çevresel uyaran yoğunluğunda hissettikleri gerginliğin, utangaçlığın ve çekingenliğin 'dur-ve-kontrol et' sisteminin tetiklenmesi sonucunda daha ayrintılı ve derin bilişsel işlemleme süreci geçirmelerinden kaynaklandığı söylenebilir. Hassas olmayan kişiler ise yeni veya alış11madık bir durumla karşı karşıya kaldıklarında bunu görece daha kolay uyum sağlamaları ve deneyimi devam ettirmeleri beklenir. Aşırı hassas kişilerin yaşadığı psikolojik ve fizyolojik uyarılma durumları, özellikle diğer insanlar tarafindan izlenildiği bilindiğinde ya da aynı anda birden fazla görevin yerine getirilmesi istendiğinde daha da artmaktadır.

DİH bazı bireylerin bilişsel ve davranışsal süreçlerini yorucu hale getirse de birçok avantajı da beraberinde getirmektedir (Aron, 2011). Aşırı hassas kişiler bilişsel süreçlerinin hassas işlemleme özelliği nedeniyle çevre- 
lerindeki insanların anlık duygu durumlarının farkına varma ve daha doğru bir şekilde yorumlama yeteneğine sahiptirler. Bu özellikler aşırı hassas kişilere beraberinde empati yapma yeteneğini de getirmiştir. Tüm bu olumlu özellikler düşünüldüğünde aşırı hassas kişilerin iletişim becerilerinin daha gelişmiş olduğu söylenebilir.

İç dünyaları diğer kişilere kıyasla daha karmaşık olduğundan aşırı hassas kişilerin sanat ve müzik gibi estetik değerlere özel bir ilgi ve hassasiyetleri vardır (Aron, 2004; Aron ve Aron, 1997). Dolayısıyla, hassas kişilik özelliği sıklıkla sanatçılarda (Rizzo-Sierra, Leon-S ve Leon-Sarmiento, 2012) ve üstün yetenekli insanlarda (Mendaglio, 2003) daha yaygın görülmektedir. Beraberinde sezgileri daha kuvvetli ve yaratıcılıkları daha gelişmiştir. Estetik duyguları gelişmiş olan aşırı hassas kişilerin kırılgan, içekapanık ve utangaç olarak görülmelerinin bir diğer sebebi de bu kişilerin iç dünyalarına verdikleri önemin dış dünyalarına verdikleri önemden daha fazla olmasından kaynaklanmaktadır.

Buna karşıt sav ise aşırı hassas kişilerin özellikle çevresel uyaranlara maruz kaldıklarında yaşadıkları tepkiselliğin çoğu zaman kendileri için bir dezavantaj oluşturabileceğini savunmaktadır. Örneğin, Gearhart ve Bodie (2012) DİH ile iletişim korkusu arasında anlamlı bir ilişki bulmuştur. DİH, özellikle topluluk önünde ya da yabancı biri ile konuşurken zorlanmaya (Aron, 2004) ya da romantik ilişkilerde yaşanan tartışma anlarında ses tonu ya da mimik gibi farketmesi zor detaylara odaklanılarak tartışma probleminin istenmeyen boyutlara gelmesine sebebiyet verebilmektedir (Aron, 2011). DİH'in iletişim üzerindeki olası olumsuz etkileri yanında romantik ilişkileri de olumsuz yönde etkileyebilecek bazı dezavantajları da söz konusudur. Özellikle çiftlerden sadece birinin aşırı hassas olduğu durumlarda olumsuz etkiler daha da artabilmektedir. Bunun olası sebepleri ortak aktivite bulmak konusunda zorlanmaları, tartıșma anında hassas bireyin kendini geri çekerek tartışmanın vermiş olduğu aşırı uyarılmadan kaçması, aşırı hassas partnerin hassas olmayan partner tarafindan duygusal olarak melankolik ve bunalımlı olarak nitelendirilmesi ve hassas olmayan tarafın aşırı hassas kişi tarafından rahatsız edici düzeyde konuşkan, risk almayı seven ve heyecan arayan biri olarak değerlendirilmesi şeklinde sıralanabilir (Aron, 2011). Çiftler arasında yaşanan bu uyumsuzluk beraberinde ilişki doyumunun düşmesine sebep olabilmektedir (Şengül-İnal, 2014). Özetle, DİH'in aşırı hassas kişilere getirdiği birtakım olumlu ve olumsuz etkilerinin olduğunu söylenebilir.

\section{Duyusal İşlemleme Hassasiyeti’nin Ölçülmesi}

DİH'in ölçülmesi ile ilgili araştırmalar öncelikle Aron ve Aron'un (1997) niteliksel araştırmaları ile başlamıs ve ardından yapılan nicel araştırmalar ile son şeklini almıştır. Aron ve Aron (1997) Kaliforniya Üniversitesi'ndeki psikoloji bölümü öğrencilerinden oluşan örneklem ile yaptıkları ilk niteliksel çalışmada kendisini içekapanık ve utangaç olarak tarif eden ve şiddetli uyaranlara hassasiyet gösteren kişilerle derinlemesine mülakatlar yapmışlardır. Her biri 2-3 saat süren mülakatlar ışığında katılımcıların duyusal hassasiyeti nasıl tanımladıkları sorulmuş ve bu konu ile ilgili düşünceleri ve yaşadıkları deneyimler derinlemesine incelenmiştir. Kendilerini hassas olarak ifade eden katılımcilar, bu özelliğin onların okul yaşantılarını, kariyerlerini ve yakın ilişkilerini olumsuz yönde etkilediğini, özellikle yoğun günlerinde sık sık mola verme gereksinimini duyduklarını, beklenmedik durumlardan ve uyaranlardan uzaklaşmak istediklerini, iç dünyalarına özellikle de rüyalarına oldukça önem verdiklerini ve başkası tarafından gözlemlenirken hata yapma korkularının ve kaygılarının daha da arttığını beyan etmişlerdir. Katılımcıların hassasiyet üzerine deneyimledikleri durumlar DİHÖ’nin maddelerinin oluşturulmasına 1şık tutmuştur.

Aron ve Aron'un (1997) peşi sıra yaptıkları altı çalışmada DİH'in ölçümü için geliştirilen 60 madde birbiriyle uyumlu 27 maddeye indirgenmiştir. Ölçek maddeleri özetle yüksek ses, parlak ışık gibi güçlü uyaranlardan rahatsız olma, kolay irkilme, çoklu görev esnasında aşırı uyarılma ve estetik değerlere önem verme gibi duyusal hassasiyet belirleyicilerini kapsamaktadır. Ölçek maddelerinde anlatılan durumlara yatkınlık katılımcılar tarafından yedi aralıklı ölçekle ile derecelendirilmektedir.

Çalışmalarda aynı zamanda DİHÖ'nin yapısal geçerliliği kavramsal olarak yakın ilişkili olduğu düşünülen sosyal içekapanıklık ve olumsuz duygulanım ölçekleriyle test edilmiştir. Araştırmaların bulguları 27 maddeden oluşan DİHÖ’nin yeterli iç tutarlılığa sahip tek faktörlü yapıdan oluştuğunu göstermiştir. Çalışmada DİH'in sosyal içekapanıklık ile orta derecede, olumsuz duygulanımla ise güçlü derecede ilişkili bulunmuştur. Ancak, DİH'in ayrı bir kurultu olduğunu destekler şekilde ele alınan değişkenlerin DİH ile örtüşmediği de görülmüştür. DİHÖ'nin tek boyutlu faktör yapı geçerliliği araştırması (yakınsama ve ayırt edici geçerliliği) ölçeğin Eysenck'in dişadönüklük kişilik boyutu ve Beş Büyük kişilik özellikleri ile ilişkisinin orta düzeyde olduğunu göstermiştir. Özetle, DİHÖ'nin bu kişilik özellikleriyle ilişkili ancak bu özelliklerden farklı ve bağımsız bir kişilik özelliği olan DİH'in ölçümü için kullanılabilecek geçerli ve güvenilir bir ölçek olduğu gösterilmiştir (Aron ve Aron, 1997; Smolewka ve ark., 2006).

DİHÖ’yi kullanan ilk araştırmacılar ölçeğin tek faktörlü ve istenilen düzeyde iç tutarlılık katsayısına sahip bir ölçek olduğunu bulmuşlardır (Hofmann ve Bitran, 2007; Neal, Edelmann ve Glachan, 2002). An- 
cak, daha sonraki çalışmalar DİH Ölçeğinin çok boyutlu faktör yapısına sahip olduğuna işaret etmektedir. Meyer, Ajchenbrenner ve Bowles'in (2005) DİH Ölçeği'nin psikometrik özelliklerini klinik tanı almamış örneklem üzerinde analiz etmiş ve ölçeğin dört alt boyuttan oluştuğunu bulmuşlardır. Bu alt boyutlar şu şekilde sıralanmıştır; (1) duyusal uyaranlar karşısında aşırı uyarılmayı temsil eden Genel Hassasiyet/Aşırı Uyarılma (General Sensitivity/Overstimulation), (2) duyusal uyaranlara gösterilen aşırı tepkisellik durumunu temsil eden Güçlü Uyarıcılara Karşı Tepkisellik (Adverse Reactions to Strong Sensations), (3) güzel sanatlara karşı ilgiyi temsil eden Estetik Farkindalık (Psychological Fine Discrimination), (4) potansiyel tehlike ve olumsuz durumlarda bilinçli davranışsal kaçınmayı temsil eden Kontrollü Zarardan Kaçınma (Controlled Harm Avoidance). Takip eden çalışmada, DİH Ölçeği'nin (1) dış kaynaklı uyaranlardan rahatsız olma durumunu temsile den Düşük Duyusal Eşik (Low Sensory Threshold), (2) iç ve dış kaynaklı duyusal uyaranlar karşısında kolay uyarılmayı temsil eden Kolay Uyarllma (Ease of Excitation), ve (3) estetik değerler karşısında aşırı uyarılma durumunu temsil eden Estetik Hassasiyet (Aesthetic Sensitivity) olmak üzere üç alt boyuttan oluştuğu ve bu üç alt boyutun birbirleri ile orta düzeyde korelasyon gösterdikleri bulunmuştur (Smolewska ve ark., 2006). Takip eden çalışmalarda her ne kadar düşük madde korelasyon değerleri (Evers, Rasche ve Schabracq, 2008) ve model sınama analizlerinde üçlü faktör modeli için uyum zayıf düzeyde bulunsa da (Liss, Mailloux ve Erchull, 2008), üç boyutlu faktör yapısının mevcut veri seti için daha uygun olduğu belirtilmiştir.

Evans ve Rothbart (2008) DİH Ölçeği'nin faktör yapısını Yetişkin Mizaç Ölçeği ile karşılaştırarak incelemiş ve DİH Ölçeği'nin temelde yetişkin mizaç özelliklerinden (1) Negatif Duygulanım (Negative Affectivity) ve (2) Uyaranlara Duyarlllık (Orienting Sensitivity) boyutlarını temsil eden iki alt boyuta indirgenebileceğini savunmuşlardır. Yakın zamanda, Grimen ve Diseth (2016) DİH Ölçeği'nin faktör yapısını Norweçli örneklem üzerinde test etmişler ve ölçeğin üç boyutlu faktör yapısına uygunluğunun ancak madde sayısı azaltılarak elde edilebileceğini savunmuşlardır. Ölçeğin faktör yapısını iki ayrı Türk örneklemi üzerinde test eden Şengül-İnal ve Sümer (2017), ölçeğin iç tutarlılığı yüksek dört faktörlü psikometrik yapıya sahip olduğunu bulmuşlardır. Bu dört faktör (1) Dış Uyaranlara Hassasiyet (Sensitivity to External Stimuli), (2) Estetik Hassasiyet (Aesthetic Sensitivity), (3) Zarardan Kaçınma (Harm Avoidance) (4) Aşırı Uyarılmaya Hassasiyet (Sensitivity to Overstimulation) olarak adlandırılmıştır. Ölçek Türk örneklemi üzerinde DİS, DAS, Sosyal içekapanıklık ve Beş Büyük Kişilik özellikleri gibi dışsal doğrulayıcıları olan ilişkisi incelendiğinde, beklendiği gibi ölçeğin DİS, DAS ve sosyal içekapanıklık ile orta dereceli ilişkili olduğu görülmüştür. Kişilik özellikleriyle olan ilişkisine bakıldığında DİH alt boyutlarının kişilik özellkleriyle eşit derecede ilişkili olmadığı, aksine farklı kişilik özellikleriyle ilişkisinin değişkenlik gösterdiği gözlemlenmiştir. Örneğin, duygusal tepkisellik boyutu ayrıcalıklı olarak nörotisizmle ilişkili bulunurken, deneyime açıklık özelliği güçlü bir şekilde estetik hassasiyet boyutu ile ilişkili bulunmuştur. Türkçe DİH Ölçeği'nin alt boyutlarının dışsal doğrulayıcılar ile farklılaşan ilişki göstermesi ölçeğin çok boyutlu olarak kullanılmasının önemini bir kez daha vurgulamaktadır.

Özetle, geçmiş çalışmalarda DİH Ölçeği'nin faktör yapısıyla ilgili çelişkili bulgular elde edilmiştir. Ancak, Türkiye'de yapılan çalışmaya benzer şekilde son yıllarda yapılan çalışmalar da ölçeğin çok boyutlu faktör yapısı desteklenmiştir. Bu bulgular ışığında araştırmalar ağırlıklı olarak ölçeğin alt boyutlarının keşfedilmesine odaklanmıştır. DİHÖ Ölçeği’nin faktör yapısıyla ilgili çelişkili sonuçlar elde edilmiş olmasına karşın, bulgular DİHÖ'nin DİH'in ölçümü için güvenilir ve geçerli bir ölçek olduğunu göstermiştir.

\section{DİH Üzerine Yapılan Çalışmalar}

Psikoloji yazınında DİH üzerine yapılan çalışmalar Web of Science, PsycARTICLES, PsycINFO ve EBSCOhost veri tabanlarında taranmıştır. Veri tabanlarının arama motorlarında kullanılan anahtar kelimeler şu şekildedir; (1) 'sensory processing sensitivity', (2) 'sensory sensitivity' ve (3) 'highly sensitive people'. Kullanılan bu anahtar kelimeler öncelikli olarak başlıkta taranmış olup, sonrasında sırasıyla özet ve tüm metinde tarama yapılmıştır. Bu ölçütlere ek olarak DİH ile ilgili öncü yayın olan Aron ve Aron'un 1997 makalesini alıntılama yapan yayınlar da gözden geçirilmiştir. Duyusal hassasiyet, mizaç yazınında oldukça sık kullanılan kelime grubu olduğundan, duyusal hassasiyetin özellikle Aron ve Aron'un (1997) kavramsallaştırdığı şekilde ele alınmış olması ve araştırmada DİH Ölçeği'nin kullanılmış olması esas alınmıştır. Bu derleme çalışmasına sadece İngilizce dilinde yayınlanmış görgül araştırmalar dâhil edilmiş olup, yazın inceleme ve kuramsal makaleler dâhil edilmemiştir.

Tarama sonucunda yukarıda sayılan temel ölçütleri karşılayan toplam otuz beş DİH üzerine yayınlanmış görgül araştırmaya ulaşılmıştır. Bu derleme çalışmasında elde edilen görgül araştırma bulguları altı ana başlık altında, (1) kişilik özellikleri, (2) olumsuz psikolojik etkiler, (3) psikolojik iyi oluş, (4) nörobilimsel ve genetik bulgular, (5) birey-çevre etkileşimine yönelik bulguları ile bu gruplara girmeyen (6) diğer bulgular altında gruplandırılmıştır. 


\section{Kişilik Özellikleri}

Aron ve Aron (1997) ilk çalışmadan başlayarak DİH kavramı ile çok sayıda kişilik kuramı arasındaki ilişkiyi tartışmıştır. Bu nedenle, DİH üzerine yapılan çalışmalar özellikle temel kişilik özelliklerine odaklanmıştır. Aşırı hassas kişilerin sıklıkla içekapanık, nörotik ve çekingen olarak tarif edilmesi DİH'in bu kişilik özellikleriyle birçok yönden örtüşmesinden kaynaklanmaktadır. DİH kavramının temel kişilik özellikleriyle ne kadar benzeştiği ve bu özelliklerden ne kadar ayrıştığ özellikle DİHÖ'nin geçerlilik ve güvenilirlik analizleri ile araştırılmıştır (örn., Smolewska ve ark., 2006). Örneğin, Aron ve Aron'un (1997) öncül çalışmasında DİHÖ, farklı örneklemler üzerinde ve her çalışmada farklı bir kişilik özellikleri ölçümleri kullanılarak içekapanıklık ve nörotisizm kişilik özellikleriyle ilişkisi test etmişlerdir. Takip eden çalışmalarda ise DİHÖ sıklıkla Beş Büyük Kişilik Özellikleriyle (nörotisizm, dişadönüklük, sorumluluk, uyumluluk ve deneyime açıklık) olası ilişkisi açısından incelenmiştir. Bulgular DİH'in özellikle nörotisizm, içekapanıklık ve deneyime açıklık ile yakından ilişkili olduğunu göstermiştir (Ahadi ve Basharpoor, 2010; Grimen ve Diseth, 2016; Licht, Mortensen ve Knudsen, 2011; Smolewska ve ark., 2006; Sobocko ve Zelenski, 2015; Şengül-İnal, Kırımer-Aydınlı ve Sümer, 2018). Bu çalışmalarda bu kişilik özelliklerinin etkisi kontrol edildiğinde de DİH ile diğer duyusal hassasiyet göstergeleri (örn., günışı̆̆ hassasiyeti, yalnız vakit geçirme isteği, yoğun rüya görme gibi) arasındaki ilişkisinin istatistiksel olarak devam ettiği gözlemlemiştir. Dolayısıyla, DİH'in Beş Büyük Kişilik Özellikleri arasından belirgin bir şekilde içekapanıklık ve nörotisizm ile benzeştiği fakat bu kişilik özeliklerinden bağımsız farklı bir mizaç özelliği olduğu istatiksel olarak doğrulanmıştır. Duyusal işlemleme hassasiyetine sahip bireylerin yaklaşık üçte birini oluşturan kişilerin dişadönük kişilik yapısına sahip olması da bu bulguları destekler niteliktedir (Aron ve Aron, 1997).

Bu bulgulara ek olarak DİH'in aynı zamanda olası tehlike ve zarar verici durumlardan kaçınma eğilimi olarak tanımlanan zarardan kaçınma özelliği ile de ilişkili olduğu bulunmuştur (Hofmann ve Bitran, 2007; Licht ve ark., 2011). DİH ve Gray'in biyopsikolojik kişilik teorisinin temellerini oluşturan DİS ve DAS özellikleri arasındaki teorik ilişki göz önünde bulundurulduğunda DİHÖ’nin DİS ve DAS ölçümleri ile yakından ilişkili olması beklenmektedir. Bu teorik varsayımla oluşturulan araştırma bulguları DİH ve DİS arasında güçlü ilişki olduğunu, DİH'in DAS ile ilişkisinin ise zayıf ama anlamlı olduğunu göstermiştir (Smolewska ve ark., 2006; Sobocko ve Zelenski, 2015).

İlgili yazında DİHÖ'yi tek boyutlu faktör yapısı ile analiz eden çalışmaların yanı sıra çok boyutlu faktör yapısıyla inceleyen araştırmalar da dikkat çekmektedir. Bu araştırmalar özellikle Smolewska ve arkadaşlarının (2006) DİHÖ için önerdiği üç boyutlu faktör yapısıyla yapılmıştır. Bulgular DİH boyutlarının kişilik özelikleri ile farklı ilişki örüntülerine sahip olduğunu göstermiştir. Örneğin, estetik duyarlılık olumlu duygulanım veya deneyime açıklık gibi daha olumlu kişilik özellikleriyle ilişkili bulunurken, düşük duyusal eşik ve kolay uyarılma boyutlarının nörotisizm ve içekapanıklık gibi daha olumsuz kişilik özellikleri ile ilişkili olduğu görülmüştür (Grimen ve Diseth, 2016; Sobocko ve Zelenski, 2015). Benzer şekilde Ahadi ve Basharpoor (2010) bu bulguları desteklemesine ek olarak estetik duyarlılık boyutunu sorumluluk özelliği ile yakın ilişkili bulmuştur.

\section{Olumsuz Psikolojik Etkiler}

DİH'in temel olarak çalışıldığı konuların başında stres ve kaygı gibi olumsuz psikolojik değişkenler gelmektedir. Neal ve arkadaşlarının (2002) büyük ölçekli araştırma projesinden elde ettikleri verilere göre yüksek düzey DİH yüksek düzey kaygı ile ilişkili bulunmuştur. Benzer şekilde, takip eden birçok çalışmada da yüksek DİH ve yüksek stres ve kaygı düzeyleri arasında anlamlı ilişki tespit edilmiştir (Ahadi ve Basharpoor, 2010; Bakker ve Moulding, 2012; Gearhart ve Bodie, 2012; Kjellgren, Lindahl ve Norlander, 2009; Liss, Timmel, Baxley ve Killingsworth, 2005; Meredith, Bailey, Strong ve Rappel, 2016). Kemler (2006) üniversite atlet takımındaki öğrencileri DİHÖ'de aldıkları puanlara göre yüksek ve düşük DİH gruplarına ayırarak DİH'in ögrrencilerin rekabet ortamlarındaki duygusal durumları üzerindeki etkisini araştırmışlardır. Bulgular yüksek düzey DİH’e sahip grubun düşük düzey DİH grubuna kıyasla daha yüksek düzey utangaçlık, kaygı ve çelişkili öz benliğe dayalı stres beyan ettiklerini göstermiştir. Aynı yıl içerisinde Benham (2006) benzer şekilde üniversite öğrencilerin DİH seviyelerini stres seviyeleri ile ilişkili bulmuştur. DİH ve stres arasındaki ilişkinin birçok araştırmada desteklenmesinden dolayı bazı çalışmalarda stresin DİH üzerindeki olası etkisinin istatistiksel olarak kontrol edilmesi amaçlanmıştır (örn., Licht ve ark., 2011).

DİH'in negatif psikolojik etkilerini konu alan birçok çalışmada DİH ile sürekli kaygı arasındaki ilişki araştırılmış olsa da DİH'in aynı zamanda yakın ilişki mekanizmalarına yönelik kaygı türlerinden olan reddedilme (Meyer ve ark., 2005) ve bağlanma kaygısıyla da (Meredith ve ark., 2016; Şengül-İnal, Kırımer-Aydınlı ve Sümer, 2018) pozitif yönde ilişkili olduğuna yönelik bulgular mevcuttur. Bu bulgular ışığında aşırı hassas kişilerin tehlike ve tehdit durumlarına karşı geliştirdikleri aşırı duyarlılığın yakın ilişkilerde bağlanma figürü tarafindan reddedilme ve terkedilme duyarlılığı olarak yansıdığı söylenebilir. Yakın ilişkilerde yaşanan terkedilme 
ve kaybetme korkusu yüksek aktivisyon stratejilerinin harekete geçmesine neden olarak DİH'e sahip bireyler için birer güçlü uyaran ve kaçınılması gereken durumlar olarak görüldükleri söylenebilir.

DİH ve olumsuz psikolojik etkiler arasındaki ilişkiyi araştıran çalışmalarda aynı zamanda ilgili değişkenlerin olası düzenleyici ve aracı rolleri de test edilmiştir. Bakker ve Moulding (2012) düşük seviye bilinçli farkındalığa sahip aşırı hassas bireylerin daha fazla kaygı belirtisi gösterdiklerini gözlemlemişlerdir. Bu anlamda bilinçli farkındalığın kaygı seviyesini düşürücü etkiye sahip olduğunu söylenebilir. Bunun yanı sıra, Brindle, Moulding, Bakker ve Nedeljkovic (2015) DİH, stres ve kaygı arasındaki ilişkinin etkili duygu düzenleme stratejilerinin eksikliği aracılığı ile sağlandığını bulmuşlardır. Yakın zamanda Uljarevic, Carrington ve Leekam (2016) tarafından yapılan bir başka çalışmada ise DİH'in kayg1 ile olan ilişskisi otistik çocuk sahibi anneler üzerinde test edilmiş ve belirsizliğe tahammülsüzlüğün bu ilişkide aracı değişken rolü oynadığı görülmüştür. Sonuç olarak, yüksek DİH'e sahip bireylerin belirsiz durum ve olayları olası bir tehdit işareti olarak görerek belirsizliğe tahammülsüzlük geliştirdikleri ve dolayısıyla kaygı seviyelerinin anlamlı derecede arttığı söylenebilmektedir.

\section{Psikolojik İyi Oluş}

Geçmiş çalışmalara bakıldığında özellikle Beş Büyük Kişilik özelliklerinin mevcut ve algılanan sağlık durumlarını yordayıcı güçte olduğu görülmektedir (örn., Chapman, Duberstein, Sörensen ve Lyness, 2006; Duberstein ve ark., 2003; Goodwin ve Engstrom, 2002). DİH'in psikoloji yazınına girmesiyle Beş Büyük Kişilik özellikleriyle birlikte DİH'in de algılanan ve mevcut sağl1k durumlarıyla ilişkili önemli bir kişilik özelliği olduğu görülmüştür. Örneğin, kayg1 ve depresyon ile ilgili danışma merkezleri üyeleri (Neal ve ark., 2002) ve üniversite öğrencileriyle (Meyer ve Carver, 2000) yapılan araştırmada elde bulgular DİH'in bireylerin kapalı ya da kalabalık yerlerde endişe ve korku duyması olarak tanımlanan agorafobi ile yakından ilişkili olduğunu göstermiştir. Meyer ve Carver (2000) DİH'i kaçınmacı kişilik bozukluğu ile ilişkili bulmasının yanı sıra bu ilişkinin kötümserlik puanının yükselmesiyle daha güçlendiği görülmüştür. Meyer ve arkadaşları (2005) DİHÖ’yi dört boyutlu kullanarak kaçınmacı ve sınır kişilik bozukluklarının farklı duyusal hassasiyet türleriyle olan ilişkisini incelemiştir. Bulgular özellikle Estetik Farkındalık boyutunun sınır kişilik bozukluğu, Kontrollü Zarardan Kaçınma boyutunun ise kaçınmacı kişilik bozukluğu ile ilişkili olduğunu göstermiştir. DİHÖ’yi üç boyutlu inceleyen Ahadi ve Basharpoor (2010) ise sosyal fonksiyon bozukluğunu Kolay Uyarılma ile ilişkilendirirken, beyana dayalı bedensel sağlık göstergelerini hem Kolay Uya- rılma hem de Düşük Duyusal Eşik boyutları ile ilişkili bulmuştur.

Neal ve arkadaşları (2002) sosyal fobi, kaygı/panik belirtileri ve depresyonun DİH üzerindeki etkisini araştırmışlar ve DİH ile sosyal fobi ve kaygı/panik belirtileri arasında güçlü ilişki tespit ederken, DİH'in depresyon ile ilişkisinin istatistiksel olarak anlamsız olduğunu görmüşlerdir. DİH ve depresyon arasındaki ilişkinin niteliği bakımnından yazında çelişkili bulgular mevcuttur. Örneğin bazı çalışmalarda DİH ve depresyon arasında istatistiksel olarak anlamlı ilişki bulunmamasının yanı sira (örn., Jonsson, Grim ve Kjellgren, 2014; Kjellgren ve ark., 2009; Meredith ve ark., 2016) depresyonun temel psikolojik bozukluk (Liss ve ark., 2005; Liss ve ark., 2008), olumsuz duygu durum (Bakker ve Moulding, 2012; Brindle ve ark., 2015; Meyer ve ark., 2005) ya da zayıf akıl sağlığı göstergesi (Ahadi ve Basharpoor, 2010) olarak ele alındığı çalışmalarda ise anlamlı bulgular elde edimiştir. Tüm bu bulgulara ek olarak, Liss ve arkadaşları (2005) yüksek seviye DİH'e sahip bireylerin kalitesiz ebeveyn bakımı aldıklarında düşük seviye DİH'e sahip bireylere kıyasla daha fazla depresyon belirtisi gösterdikleri bulunmuştur. Zayıf duygu düzenleme stratejileri, yüksek düzey duygusal farkındalık ve olumsuz duygu durumlarına tahammülsüzlüğün de DİH ve depresyon arasındaki ilişkide kısmı aracı değişkenler olarak rol oynadıkları gözlemlenmiştir (Brindle ve ark., 2015).

Kişilerin mevcut sağlık durumlarının algıladıkları sağlık durumlarıyla yakından ilişkili bulunması (örn., Heinze, Kruger, Reischl, Cupal ve Zimmerman, 2015) kişilerin kendi sağlık durumları ile ilgili algılarının da psikolojik esenlik için önemli bir ölçüm olduğunu göstermektedir. Bu bağlamda DİH'in bireylerin öznel iyi oluş düzeyiyle olan ilişkisini araştıran çalışmalar da mevcuttur. Örneğin, stresin DİH üzerindeki etkisi kontrol edildikten sonra yüksek düzey DİH bireylerin daha fazla hastalık düşüncesinde olmalarıyla ilişkili olduğu görülmüştür (Benham, 2006). Sobocko ve Zelenski (2015) DİHÖ için iki ve üç boyutlu faktör yapısını temel alarak DİH'in öznel mutluluk ile olan ilişkisini araştırmış ve öznel mutluluğun toplam DİH puanı, Estetik Farkındalık ve Uyaranlara Duyarlılık alt ölçekleri hariç diğer tüm hassasiyet boyutları ile negatif yönde ilişkili olduğunu bulunmuştur. Üç boyutlu faktör yapısını kullanan bir başka çalışmada ise (Grimen ve Diseth, 2016) Kolay Uyarılma ve Düşük Duyusal Eşik boyutları psikolojik sağlık şikâyetleri ile pozitif yönde ilişkili bulunurken, Estetik Farkındalık boyutunun ise bedensel ve psikolojik sağlık şikâyetleri ilişkili olmadığı görülmüştür. Aynı çalışmada DİH ve sağlıkla ilgili şikâyetler arasındaki anlamlı ilişkinin nörotisizmin etkisi kontrol edildiğinde yok olduğu tespit edilmiştir. 


\section{Nörobilimsel ve Genetik Bulgular}

DİH'in bazı kişilik özellikleri ve mizaç gibi ağırlıkla doğuştan gelen özellikler arasında sayılması nedeniye araştırmacılar DİH'i etkileyen biyolojik faktörleri de araştırmaya başlamışlardır. Bu konudaki araştırmalar duyusal hassasiyeti yüksek olan kişilerin buna uygun bir genetik altyapıya ve görece farklı bilişsel süreçlere sahip olduklarını göstermektedir. DİH'in biyolojik temellerini inceleyen ilk çalışma Aron ve arkadaşları (2010) tarafından gerçekleştirilmiştir. Aron ve arkadaşlarının işlevsel manyetik rezonans görüntüleme (IMRG) cihazı kullanarak yaptıkları çalışmada Asyalı ve Amerikalı olmak üzere iki gruba ayrılan katılımcılara bir takım basit görsel-mekansal görevler (visuospatial task) verilmiştir. Katılımcılardan verilen görsel-mekânsal görevler üzerine Asya kültüründen gelen katılımcılar için daha kolay olan mekâna veya çevreye dayalı (context-dependent) ya da Amerika kültüründen gelen katılımcılar için daha alış1ldık oldukları mekândan bağımsız (context-independent) değerlendirme yapmaları istenmiştir. Değerlendirme s1rasında katılımcıların beyin hareketleri iMRG cihazı ile incelenmiștir. Her iki gruptaki katılımcıların da kültürel farklılıklara maruz kaldıklarında dikkat ve işleyen bellek ile ilgili olan ön ve yan beyin loblarının daha fazla aktif olduğu gözlemlenmiştir. Fakat sonuçlar DİH'e göre değerlendirildiğinde, aşırı hassas kişiler daha az kültürel farklılık gösterirken, hassas olmayan kişilerin daha fazla kültürel farklılık gösterdikleri görülmüştür. Başka bir deyişle, duyusal hassasiyeti olan kişiler algısal değerlendirmelerinde kültürel durumlardan daha az etkilenerek, yani kültürel etkileri aşarak, uyarıcılara daha fazla dikkat etmişlerdir.

Benzer bir çalışmada ise Jagiellowicz ve arkadaşları (2011) üniversite öğrencilerinden, verilen manzara resimleri arasındaki benzerlik ve farklılıkları değerlendirmelerini istemişler ve bu değerlendirme sırasında beyin aktivitelerini iMRG aracılığıly izlemişlerdir. Duyusal hassasiyeti olan öğrencilerin hassas olmayanlara kıyasla özellikle görsel zekâ ile ilgili beyin bölgelerinde daha fazla beyin hareketi gözlemlemiştir. Bu beyin hareketliliğinin özellikle fark etmesi zor detaylar incelediği sırada daha yoğunlaştığı ve aşırı hassas bireylerin bu görevi yerine getirmek için daha fazla zaman harcadıkları görülmüştür. Benzer bir çalışmada ise aşırı hassas kişilerin görsel algilama ve tespit etme görevlerinde diğer kişilere göre daha az hata yaparak daha başarılı oldukları fakat Jagiellowicz ve arkadaşlarının (2011) bulgularının aksine verilen görevleri tamamlamak için daha az süreye ihtiyaç duydukları saptanmıştır (Gerstenberg, 2012).

DİH üzerine yapılmış en güncel nörolojik bulgular Acevedo ve arkadaşları (2014) tarafindan elde edilmiş olup, elde edilen bulgular DİH yazınına olduğu kadar yakın ilişkiler yazınına da katkıda bulunmuştur. Duyusal hassasiyeti olan kișilerin dikkat, alg1, empati, ve eylem planlama ile ilgili beyin bölgelerinde daha yoğun beyin hareketleri gözlemlenmesinin yanı sıra bu bilişsel hareketliliğin özellikle partnerlerinin mutlu ve üzgün yüz ifadelerini gördüklerinde beynin ödüllendirilme gibi olumlu uyaranlara hassas olan bölgesinde daha da arttığ gözlemlenmiştir. Kısacası, DİH kişilerde duygusal uyarıcı niteliğinde olan faktörlere karşı hassasiyet geliştirilmesine neden olmakta ve bu hassasiyet beyindeki ilgili bölgeleri uyararak bu bölgelerin daha aktif bir şekilde çalışmasına sebep olmaktadır.

DİH'in genetik temellerini araştıran çalışmalar sayıca az olmasına rağmen bu kişilik özelliğinin kalıtımsal yönü hakkında önemli ipuçları vermektedir. Örneğin, Licth, Mortensen ve Knudsen (2011) hassas kişilik özelliğinin serotanin taşıyıcı 5-HTTLPR geni kısa formu ile ilişkili olduğunu ve bu ilişkinin cinsiyet, yaş, psikolojik stress ve açıklık, nörotisizm, dişadönüklük kişilik özelliklerinin anlamlı etkisi kontrol edildiğinde de devam ettiğini bulmuşlardır. Aynı yıl Chen ve arkadaşları (2011) dopamin sisteminde yer alan gen polimorfizmlerinin (örn., TH, D $\beta H$, SLC6A3, DRD2, NLN, NTSR1, NTSR2) DİH ile ilişkili olduğunu bulmuşlardır. Bu poliformizimlerin dopamin sisteminde özelikle modülasyon ve reseptör alt sistemleriyle ilişkili olması, DİH'in duyusal uyaranları algılama, yorumlanma ve uyarana uygun cevap verme işlemlerinde aktif olarak rol oynadığını göstermektedir. Chen ve arkadaşları (2015) tarafından yürütülen bir başka çalışmada ise DİH 10 özgül genetik dizilim ile anlamlı ilişkili bulunmuştur.

Özetle, DİH ile ilgili genetik bulgular bu kişilik özelliğinin serotanin ve dopamin sistemlerinde yer alan belli başlı gen ve gen çiftleriyle ilişkili olduğunu göstermektedir. Bu bulgular hassas kişilik özelliğinin kalıtımsal bir özellik olarak daha iyi anlaşılmasına katkı sağlar niteliktedir. Her ne kadar bu genetik bulgular DİH'in kalıtsal bir kişilik özelliği olduğuna işaret etse de, bu çalışmalarda genetik ve çevresel faktörleri birbirinden ayırmak oldukça güçtür. Özellikle DİH ile ilişkili bulunan serotonin (Licht ve ark., 2011) ve dopamin sistemi (Chen ve ark., 2011) ile ilgili genlerin çevresel faktörler ile etkileşime giren genler olması nedeniyle DİH'in "birey-çevre etkileşimi”" olarak adlandırılan ve biyolojik temelli özelliklerin çevresel faktörlerin etkisini belirlemede kritik bir rol oynadığını öne süren hipotezi sınayan çalışmalara dahil edilmesi DİH'in birey-çevre etkileşimi kuramları çerçevesinde de incelenmesi gerekliliğini doğurmuştur (Bkz. Homberg, Schubert, Asan ve Aron, 2016). Bu konuda yapılan çalışmalar sayıca sınırlı olmasına karşı ilgili yazın için önemli doğurguları mevcuttur. Bu bağlamda, DİH'in çevresel koşullarla olan etkileşimi üzerine yoğunlaşan çalışmalar birey-çevre etkileşimi başlığ 1 altında incelenmiştir. 


\section{Birey-Çevre Etkileşimi}

Birey-çevre etkileşimi ya da bir diğer deyişle gen-çevre etkileşimi, genlerin ya da bir takım kalıtımsal biyolojik özeliklerin çevresel koşullarla etkileşime girmesi ve buna bağlı olarak çevresel koşulların kalitesine göre davranışsal ve psikolojik çıktıların yönünü ve şiddetini belirlemesi durumu olarak tanımlanmaktadır (Dick, 2011). Birey-çevre etkileşiminin altında yatan temel sayıltı genetik geçiş ve biyolojik özeliklerin çevresel koşulların kalitesine göre bireylerde olumlu ve/veya olumsuz davranışsal ve psikolojik etkilere yatkınlık yaratmasıdır. Burada bahsi geçen davranışsal ve psikolojik etkiler stres, kaygı, olumsuz duygular, davranış bozuklukları veya birtakım psikolojik bozukluklar gibi geniş bir yelpazeyi kapsamaktadır. Psikoloji yazınında bu temel sayıltı çerçevesinde şekillenmiş üç temel kuram mevcuttur; (1) bireylerin biyolojik yatkınlığının olumsuz çevresel koşullarla bir araya geldiğinde birey için iki taraflı risk oluşturduğunu ve bu bireylerin olumsuz psikolojik ve davranışsal çıktılara daha yatkın olduğunu savunan Yatkınlık-Stres Kura$m \imath$ (Diathesis-Stress Model; Monroe ve Simons, 1991)/ İkili-Risk Modeli (Dual Risk Model; Sameroff, 1983), (2) biyolojik yatkınlığa sahip bireylerin hem olumlu hem de olumsuz çevresel koşulların etkisine daha açık olduğunu ve buna bağlı olarak bu bireylerin olumlu çevresel koşullardan daha fazla yararlandığını ve olumsuz çevresel koşullardan ise daha kötü etkilendiğini savunan Ayırıcı Yatkınlık Hipotezi (Differential Susceptibility Hypothesis; Belsky, 1997, 2005; Belsky, Bakermans-Kranenburg ve van Ijzendoorn, 2007; Belsky ve Pluess, 2009) ve (3) biyolojik duyarlığa sahip bireylerin olumlu çevresel koşullardan daha fazla yaralandığını fakat olumsuz çevresel koşulların herhangi bir etki yaratmadığını savunan Avantajlı Hassasiyet Modeli (Vantage Sensitivity; Pluess ve Belsky, 2012). Bu modellerde bahsi geçen biyolojik duyarlığa neden olan bir takım fenotip, genetik ve eşik-altı yatkınlık göstergeleri şu şekilde sıralanabilir; zorlayıcı mizaç (örn., Bradley ve Corwyn, 2008), korkuya eğilim (örn., Kochanska, Aksan ve Joy, 2007), kortizon tepkiselliği (örn., Obradovi'c, Bush, Stamperdahl, Adler ve Boyce, 2010), 5-HTTPLR k1sa aleleler (örn., Taylor ve ark., 2006), MAOA genindeki düşük aktivite (örn., Kim-Cohen ve ark., 2006), DRD4 geni (örn., Bakermans-Kranenburg ve van IJzendoorn, 2006, 2007), ve DRD2 geni (örn., Keltikangas-Jarvinen ve ark., 2007).

$\mathrm{Bu}$ üç temel yaklaşım ele alındığında hepsinde de ortak olan sav kişilerin biyolojik özelliklerinden dolayı çevresel koşullara duyarlılık geliştirmeleridir. Çevresel duyarlığa kavramsal ve kuramsal olarak benzeyen ve aynı temel sayıltılar çerçevesinde şekillenen bir diğer kişilik özelliği ise DİH’tir. Son yıllarda yapılan çalışmalarla, DİH'in maruz kalınan çevresel koşulların kalitesine göre kişilere hem bir avantaj hem de bir dezavantaj olușturabileceği önerisi getirilmektedir. DİH'in çevresel koşullarla olan etkileşimini konu alan ilk çalışma Aron, Aron ve Davies (2005) tarafından yapılmıştır. Bu çalışmada DİH'in olumsuz çocukluk yaşantıları ile etkileşimi toplam dört ayrı çalışmada incelenmiştir. Birinci çalışmanın $(N=96)$ bulguları olumsuz çocukluk deneyimi yaşayan aşırı hassas kişilerin hassas olmayanlara kıyasla daha fazla utangaçlık ve olumsuz duygulanım beyan ettiklerini göstermiştir. Aynı değişkenler için farklı ölçüm araçları kullanarak daha geniş bir örneklem $(N=213)$ üzerinde test edilen bu bulgular ikinci çalışmada da desteklenmiştir. Birinci ve ikinci çalışmanın bulguları farklı ve daha geniş bir örneklem $(N=396)$ üzerinde tekrardan test edilmiş ve önceki iki çalışmanın sonuçlarını destekleyen bulgular elde edilmiştir. Dördüncü çalışmada ise birey-çevre etkileşimi deneysel çalışma ile test edilmiştir. İki gruba ayrılan üniversite öğrencileri düşünce ve muhakeme yeteneği ile ilgili bir testin kolay ve zor versiyonlarını cevaplandırdıktan sonra duygu durumları ölçülmüştür. Araştırma bulgularına göre zor teste maruz kalan aşırı hassas kişiler testte kötü performans sergilediklerini düşünmüşler ve hassas olmayanlara kıyasla daha negatif duygu durumu beyan ederken, kolay testi cevaplayan aşırı hassas kişiler testte iyi performans gösterdiklerini düşünmüşler ve hassas olmayanlara kıyasla daha olumlu duygu durumu beyan etmişlerdir. Aron ve arkadaşlarının peşi sıra yaptıkları bu dört çalışmada DİH'in çevresel koşullar ile etkileşime girdiği ve buna bağlı olarak kişilerde değişen düzeylerde davranışsal ve duygusal etkiler ortaya çıktığı görülmektedir.

Son yıllarda yapılan çalışmalar da benzer şekilde DİH'in çevre ile etkilişimini destekler niteliktedir. Örneğin, Pluess ve Boniwell'in (2015) yaptıkları araştırmada avantajlı hassasiyet kuramına uygun olarak yüksek düzey duyusal hassasiyete sahip olan okul çağındaki kız çocuklarının duyusal hassasiyeti olmayanlarla karşılaştırıldığında depresyon etkilerini önleme programında verilen destek ve tedaviden daha fazla yararlanarak daha düşük düzeyde depresyon belirtileri gösterdikleri görülmüştür. DİH'in olumsuz çocukluk deneyimleri ile olan ilişkisini araştıran başka bir araştırmada ise yüksek düzey DİH'e sahip olan kişilerin olumsuz çocukluk deneyimleri yaşadıklarında daha az yaşam memnuniyeti gösterdikleri bulunmuştur (Booth, Standage ve Fox, 2015). DİH'in sadece olumsuz çocukluk deneyimleri ile etkileşime girmesinden dolayı Booth ve arkadaşlarının bulguları yatkınlık-stres kuramını destekler niteliktedir.

Özetle, DİH'in biyolojik yatkınlığı tetikleyen DRD2 ve 5-HTTPLR genleriyle ilişkili olduğunu gösteren bulgular, bu kişilik özelliğinin birey-çevre etkileşimi kuramlarını destekleyici önemli bir kişilik özelliği olduğunu ortaya koymaktadır (Bkz. Homberg, Schubert, Asan ve Aron, 2016). 


\section{Diğer Bulgular}

Bu başlık daha önceki başlıklar altında gruplandırılmayan DİH'in iş, ev ve sosyal ortamlar ve ruhsal dünya gibi çeşitli yaşam alanlarına olan etkisini konu alan çalışma bulgularını içermektedir. Bu kapsamda ele alınan çalışmalar, aşırı hassas kişilerin ev, iş yeri ya da çeşitli sosyal çevrelerde bu özelliğe sahip olmayan bireylerden farklı davranış biçimleri ve psikolojik süreçler deneyimlediklerini göstermektedir.

Örneğin, Evers ve arkadaşları (2008) belli bir işte çalışan kişiler ile yaptıkları çalışmada DİH'i üç alt boyutu ile incelemiş ve Kolay Uyarılma ve Düşük Duyusal Eşik boyutlarını daha az bütünlük duygusu, daha düşük iş memnuniyeti ve daha fazla işten yabancılaşma ve iş stresi ile ilişkili bulmuşlardır. Estetik duyarlılık boyutunun işle ilgili hiçbir olumsuz değişken ile ilişkili bulunmamasının yanı sıra öz yeterlilik ile pozitif yönlü ilişkili olduğu tespit edilmiştir.

Așırı hassas kișilik özelliğini ev ortamında inceleyen Wachs (2013), duyusal hassasiyeti yüksek ve düşük olan annelerin ev düzeni ile ilgili algılarını araştırmıştır. Bulgular, aşırı hassas annelerin aşırı hassas olmayan annelere kıyasla ev ortamını daha karmaşık ve kaotik algıladıklarını göstermiştir. Bu anlamda, aşırı hassas kiişlerde uyaran şiddetinin duyum eşiği sınırlarını fazlasıyla aşmasından kaynaklı olarak DİH'in kişilerin mevcut durum değerlendirmelerinde algılarını anlamlı olarak etkilediği söylenebilir.

DİH'in iletişim üzerindeki etkisini inceleyen Gearthart ve Bodie (2012), diğer insanlarla iletişim kurma ile ilgili yaşanan kaygı ve korku olarak tanımlanan iletişim korkusu ve DİH arasında anlamlı ilişki bulmuşlardır. Bu anlamda iletişim korkusu aşırı hassas kişiler tarafından fiziksel uyarılma ve stres kaynağı olarak görülmekte ve DİH iletişim korkusuna yatkınlığın öncülü olarak nitelendirilebilmektedir. Başka bir çalışmada ise Gearthart (2014) aşırı hassas kişileri deneysel ortamda dikkat dağıtıcı sese maruz bırakarak, aşırı hassas kişilerin duygusal iletişim ipuçlarını anlama ve anlamlandırma konusundaki yetilerini test etmiştir. Bulgular istatistiksel olarak anlamlı bulunmamış olsa da aşırı hassas kişilerin sesli uyaranlara maruz kaldıklarında hassas olmayanlara kıyasla duygusal ipuçlarını anlama ve anlamdırmada daha fazla hata yaptıkları gözlemlemişlerdir. Duygusal sinyalleri anlama ve tanımlama ile ilgili olarak Liss ve arkadaşlarının (2008) yaptığı çalışmada duyguları kullanma, kontrol etme ve tarif etme konusundaki yetersizlikle yakından ilişkili olan otistik belirtiler ve aleksitimi DİHÖ'nin Kolay Uyarılma ve Düşük Duyusal Eşik boyutları ile pozitif ilişkili bulunurken, Estetik Farkındalık boyutu iletişim şekillerinin etkili şekilde kullanılması ve daha iyi sosyal beceriler ile pozitif ilişkili bulunmuştur. Başka bir çalışmada ise aşırı hassas kişilerin hassas olmayan kișilere kıyasla özellikle duygusal yakınlık yaşadıkları kişilere karşı daha fazla olumlu duygusal uyarılma yaşadıkları ve bu uyarılmanın olumlu çocukluk deneyimleri yaşayan aşırı hassas kişilerde daha fazla olduğu görülmüştür (Jagiellowicz, Aron ve Aron, 2016). Duygular ve sosyal beceriler üzerindeki güçlü etkisi dolayısıyla DİH'in bireylerin duygusal ve sosyal gelişimlerini yordamada önemli katkıda bulunacağ 1 düşünülebilir.

DİH'in iş, ev ve sosyal ortamlarındaki etkisinin yanı sıra aynı zamanda değişen bilinç durumları ve doğaüstü (mistik) deneyimler gibi birtakım parapsikolojik değişkenlerle olan ilişkisi de araştırılmıştır. Bu konuda bulgular elde eden çalışmaların ikisi katılımcıları uyarıcılardan tamamen arındırılmış yüzdürme tanklarında yaşadıkları mistik deneyimler bakımından incelenmişlerdir. Yüzdürme tanklarının kullanılmasındaki amaç 1şık, ses, sıcaklık gibi dış kaynaklı fiziksel ve zihinsel uyarıcıları yok ederek duyusal yoksunluk yaratmak ve bu sayede kişilerin beden dışı iç dünyaları ile ilgili değerlendirme yapmalarını sağlamaktır. Yüzdürme tanklarından elde edilen bulgular, aşırı hassas kişilerin hassas olmayanlara kıyasla daha fazla mistik deneyim ve değişen bilinç durumları beyan ettiklerini göstermiştir (Jonsson ve ark., 2014; Kjellgren ve ark., 2009). D1ş kaynaklı uyarıcılarla tamamen ilişkisi kesilen aşırı hassas kişiler iç kaynaklı uyaranlara daha fazla yoğunlaşma olanağı bularak mistik deneyim yaşamaya daha yatkın hale gelmektedirler. Irwin, Schofield ve Baker (2014) tarafindan yapılan kesitsel çalışmada ise Kolay Uyarılma ve Düşük Duyusal Eşik boyutlarında yüksek puan alan aşırı hassas kişiler normal dışı olay ve durumlara daha fazla atıf yaptıklarını ve daha fazla ruhsal deneyim yaşadıklarını beyan etmişlerdir. DİH ve mistik deneyimler arasındaki ilişki hem parapsikoloji hem de DİH yazınına önemli katkılar sağlamaktadır.

\section{Genel Tartışma ve Öneriler}

Bir yetişkin mizaç özelliği olan DİH, utangaçlık, içekapanıklılık ve negatif duygulanım gibi kavramları aynı çatı altında toplayarak, ne bu kavramlarla birebir aynı ne de bu kavramlardan tamamen bağımsız bir kişilik özelliği olarak psikoloji yazınında yerini almıştır. Biyolojik temellerini belirlemek amacıyla yapılan çalışmalar ise DİH'in kalıtımsal bir mizaç türü olduğunu ortaya koymuştur (örn., Chen ve ark., 2011). Ölçümü Aron ve Aron (1997) tarafından gelişirilen 27 maddelik DİHÖ ile yapılan DİH, davranışsal inhibisyon ve yoğun bilişsel süreçler dolayısıyla dış ve iç kaynaklı uyaranlara karşı aşırı duyarlılık olarak kendini gösteren genetik temelli bir kişilik özelliğidir (Aron ve ark., 2012). Bu derleme çalışmasının amacı batılı psikoloji yazınında oldukça ilgi gören DİH kavramını Türkçe psikoloji yazınına tanıtmak 
ve konu ile ilgili Türkçe kaynak eksikliğini gidermektir. Türk psikoloji yazınında bu eksik düşünüldüğünde, bu çalışma Türkiye'de bu konu üzerine yapılan ilk derleme çalışması olması yönünden önemli katkısı olacaktır.

$\mathrm{Bu}$ çalışmada psikoloji veritabanlarında ve arama motorlarında yapılan inceleme sonucunda elde edilen 35 görgül çalışmanın bulguları 7 başlık altında gruplandırılmıştır. DİH çalışmalarının yıllara göre dağılımı incelendiğinde elde edilen 35 görgül araştırmanın \% 63'ünün son altı yıl içerisinde yayınlanan çalışmalar olduğu görülmektedir. Bu da DİH'in son y1llarda araştırmacilar arasında büyük bir ilgi uyandırdığını göstermektedir. DİH göreli yeni bir kavram olması ve birçok bilinmeyenin bulunması, önümüzdeki yıllarda da araştırmacılar tarafından aynı ilgiyle inceleneceğini işaret etmektedir.

Özetlenen araştırma bulgularına bakıldığında, DİH'in ağırlıklı olarak kaygı, stres, ya da psikolojik bozukluk belirtileri gibi olumsuz değişkenlerle ilişkili olduğunu görülmektedir. DİH'in öncülü olarak nitelendirilen ve kuramsal temelini oluşturan DİS hassasiyetinin kayg1 ve depresyon gibi olumsuz psikolojik değişkenlerle yakından ilişkili olması (Johnson, Turner ve Iwata, 2003) bu bulguları destekler niteliktedir. Bu tür olumsuz psikolojik etkilerin ortaya çıkmasına katkı sağlayan bir diğer sebep ise aşırı hassas kişilerin geliştirdikleri tipik dur-ve-kontrol et davranışıdır. Dur-ve-kontrol-et davranışı karşılaşılan olay ve durumlar için gösterilecek tepkileri yönlendiren ve gelecekte karşılaşılacak olası aynı durumlar için davranışsal repertuar oluşturan önemli bir rehber görevi görmektedir. Bu süreçte tetiklenen psikolojik gerginlik, stres ve kaygı temelde aşırı hassas kişiler için koruyucu ve işlevsel bir mekanizma olarak düşünülebilir. Kayg1 ve stres gibi olumsuz duygu durumlarının aşırı hassas kişileri sürekli tetikte tutararak potansiyel duygusal olumsuzluklardan koruyarak daha işlevsel bir hal aldığı söylenebilir. Benzer şekilde, aşırı hassas kişilerin duyusal uyaranlara karşı tetikte olma durumları, onları olası çevresel tehditleri daha hızlı farketme ve anında müdahele etme olanağı tanımaktadır. Özetle, DİH'in beraberinde getirdiği olumsuz psikolojik çıktıların ve gelişmiş bilişsel işlemleme kapasitesinin kişiyi olası içsel ve dışsal tehlikelerden korumak adına işlevsel olduğu söylenebilir. Buna karşın bu zamana kadar yapılan çalışmalara bakıldığında DİH'in avantajları ve işlevselliği üzerine yapılmış görgül çalışmaların eksikliği dikkat çekmektedir. DİH'in kişilere sağladığı avantajlarında azımsanmayacak kadar çok olduğunu vurgulayan Aron (2004) ve Zeff (2015), DİH'in aşırı hassas kişlerin hassas olmayan kişilere kıyasla daha yaratıcı olması, daha gelişmiş duyu ve duygu algılama becerilerine sahip olmaları, empati yapma yeteneklerinin ve sorumluluk duygularının daha yüksek olması gibi pek çok avantajı da beraberinde getirdiğini belirtmektedirler. $\mathrm{Bu}$ anlam- da DİH'in çok çeşitli bireysel ve sosyal alanlarda etki göstermesi muhtemeldir. Bu anlamda, gelecekte bu konu üzerine çalışmaların yapılması ilgili yazına katkı sağlayabilecek niteliktedir.

DİH üzerine elde edilen bulgulara genel olarak bakıldığında DİH yazınının iki önemli noktada sınırlı kaldığı görülmektedir. Birinci eksiklik DİH'in kültürleraras1 karşıllaştırma çalışmalarında incelenmemiş olmasıdır. Bu çalışma kapsamında ele alınan çalışmaların Amerika ve/veya Avrupa toplumlarında yapılmış olması DİH'in kültürlerarası farklılıkları ile ilgili somut bulgular sunulmasını kısıtlamaktadır. Ancak, biyolojik temelli bir kişilik özelliğinin kültürlerarası değişmez olduğu varsayılıyor olmasına karşın mizaç özelliklerinin dışavurumunda kültürel bağlam temelindeki beklentiler ve kültürel değerlerinin de önemli kültürel farklılıklar yaratabileceği söylenmektedir (Ahadi, Rothbart ve Ye, 1993). Örneğin, batı kültürlerinde (örn., Amerika) hassasiyet göstergesi olarak kabul edilen bir davranış ya da duygusal bir tepki doğu kültürlerinde (örn., Japonya) alışılagelmiş bir rutin ya da alışkanlık olabilir. Dolayısıyla aynı davranış bir kültürdehassasiyet belirtisi olarak algılanırken bir başkasında aynı şekilde algılanmayabilir. Başka bir deyişle, DİH'in kavramsal olarak tanımı kültürlerarası ortak paylaşılsa da kapsam ve içeriği kültürel norm ve değerlerle şekil alabilir ve kültürden kültüre farklılaşabilir. Örneğin, içekapanıklık özelliği ilişkiselliği ön plana çıkaran toplulukçu kültürlerde grup harmonisini ve toplumsal bağl1lığı arttırmaya olanak sağlarken, bireyci kültürlerde özerk benliğin gelişmesini ve sürdürülmesini tehdit edici bir unsur olarak olarak görülebilir (Markus ve Kitiyama, 1991). Benzer şekilde utangaçlık bireyci kültürü temsil eden Kanada'da akran kabülü ve sosyal kaynaşma açısında olumsuz bir özellik olarak görülürken, toplulukçu kültür olan Çin'de sosyalleşme, liderlik ve akran kabülü açısından olumlu olarak değerlendirilmektedir (Chen, Rubin ve Sun, 1992). Geçmiş çalışmalarda Beş Büyük Kişilik özelliğinin kültürlerarası dışavurumlarında farklilik tespit edilmesi (Bkz. McCrae, Zonderman, Costa, Bond ve Paunonen, 1996), DİH özelliğinin de kültürel bağlam içerisinde davranışsal ve psikolojik dışavurumlarının ve işlevselliğinin değişebileceği ihtimalini doğurmaktadır. Dolayısıyla, bu zamana kadar DİH ile ilgili test edilen savların kültürel bağlam içerisinde tekrardan incelenmesi hem DİH hem de kültürlerarası psikoloji yazınına önemli katkılar sağlayacak niteliktedir.

İkinci eksiklik ise DİH'in yakın ilișki (romantik ilişki, evlilik, arkadaşlık gibi) süreçlerine olan etkisiyle ilgili bulgulardır. DİH'in yakın ilişki birleşenlerinden olan bağlanma (Meredith ve ark., 2016) ve reddedilme kaygısı (Meyer ve ark., 2005) ile ilişkili bulunması, yakın ilişki kalitesini ve çiftlerin mutluluğunu etkileyebilecek kritik bir kişilik özelliği olduğuna işaret etmek- 
tedir. Ancak, DİH'in yakın ilişki süreçlerine olan etkisi yeterince çalışılmamıştır. Bu kısıtlılığa rağmen DİH'in duyguların tanımlanması, anlamlandırılması ve uygun iletişim şekillerinin belirlenmesinde etkin rol oynad1ğ1 düşünülürse yakın ilişkilere etkisi üzerine birtakım çıkarımlar yapmak mümkündür. Örneğin, duyusal hassasiyeti yüksek kişilerin yakın ilişkilerinde partnerinin duygu durumuna ve duygusal ihtiyaçlarına karşı hassasiyet göstermesi ve buna uygun tepkiler geliştirmesi ilişkiden algılanan doyumu olumlu yönde etkileyebilir. Tam tersine hassasiyeti düşük kişiler ise partnerinin duygusal ihtiyaçlarını anlama ve anlamlandırmaya kayıtsız kalarak ilişkilerinde daha fazla sorun yaşayabilirler. Geçmiş çalışmalarda DİH ile yakından ilişkili bulunan nörotisizim, dışadönüklük ve deneyime açıklık gibi kişilik özelliklerinin yakın ilișkilerde doyumu ve çiftler arası uyumu etkilemesi bu savı destekler niteliktedir (Karney ve Bradbury, 1995; Noftle ve Shaver, 2006). Benzer şekilde, toplumsal cinsiyet yönelimlerinden olan kadıns1lığın DİH ile ilişkili bulunması ve bu ilişkinin biyolojik cinsiyetin etkileri kontrol edildiğinde de devam etmesi DİH'in yakın ilişkilerde çiftler arası uyumu ve ilişki kalitesini yordamada etkili rol oynayabileceğini göstermektedir (Şengül-İnal ve Sümer, 2016).

DİH Ölçeği'nin faktör yapısı ile ilgili araştırmalara baktığımızda birbiriyle tutarsız bulguların olduğu görülmektedir. Elde edilen bulguların birbirinden farklı olması çalışma bulgularının karşılaştırılması ve genel bir sonuca varılması konusunda problemler oluşturmaktadır. Kısaca özetlenecek olursa, DİH Ölçeği'nin orijinal çalışmasında tek faktörlü yapı uygun görülürken (Aron ve Aron, 1997), daha sonraki çalışmalarda çok faktörlü yapı önerilmiştir (örn., Smolewska ve ark., 2006; Evans ve Rothbart, 2008). Benzer şekilde, Türk örneklemi üzerinde test edilen DİH Ölçeği için çok boyutlu faktör yapısı itibariyle geçmiş çalışmalarla uyumluluk gösterse de dört boyutlu faktör yapısı geçmiş çalışmalardan farklılaşmaktadır (Şengül-İnal ve Sümer, 2017). Bunun yanı sıra, çok faktörlü ölçek yapısı önerisinde bulunan çalışmalar ölçek maddelerinin boyutlandırılması ve maddelerin faktörler arasındaki dağılımı konusunda da birbiriyle çelişkili bulgular elde etmişlerdir. Örneğin, DİH Ölçeği'ni genel ölçek puanı ile kullanan çalışmalarda DİH ile depresyon pozitif ilişkili bulunurken (örn., Liss ve ark., 2005), DİH'i birden fazla alt boyut puanları ile değerlendiren çalışmalarda ise depresyon DİH'in bazı alt boyutlarıyla ilişkili bulunmamıştır (örn., Liss ve ark., 2008). Benzer şekilde Sobocko ve Zelenski (2015) çalışmasında DİH Ölçeği'nin bazı boyutlarını olumlu değiş̧kenler (örn., kaliteli iletişim becerileri) ile ilişkili bulurken, bazı boyutlarını olumsuz değişkenler (örn., olumsuz duygulanım) ile ilişkili bulmuşlardır. DİH Ölçeği'nin farklı boyutlarının farklı yordayıcılarının bulunmasından dola- yı gelecekteki araştırmalarda DİH ile ilgili hipotezlerin hem genel ölçek puanı hesaplanarak hem de ölçek alt boyutlarının puanları hesaplanarak test edilmesi bulguların daha doğru ve eksiksiz yorumlanmasını sağlayacaktır.

DİH'in özellikle 2010 yılından sonra genetik çalışmalarla incelenmesi bu mizaç türünün serotonin (Licht ve ark., 2011) ve dopamin (Chen ve ark., 2011) sistemi ile ilgili genlerle ilişkili olduğunu göstererek DİH'in biyolojik temellerinin daha iyi anlaşılmasını sağlamıştır. DİH'in biyolojik duyarlığa sebep olan gen ve polimorfizimlerle ilişkili bulunması, DİH'in çevresel koşullarla etkileşime girerek şiddeti ve yönü değişen özeliklerde etki yaratmasını olası kılmış ve Homberg ve arkadaşlarının (2016) ve Aron ve arkadaşlarının (2012) da önerisiyle bu özelliğin birey-çevre etkileşimi kuramları çerçevesinde incelenmesi gerekliliğini doğurmuştur. $\mathrm{Bu}$ anlamda gelecek çalışmalarda özellikle deneysel desenlerle çeşitli çevresel koşullar oluşturularak DİH'in etkilerinin incelenmesi ilgili yazına büyük katkı sağlayacak niteliktedir.

$\mathrm{Bu}$ derleme çalışmasıyla birlikte DİH'in Türkçe psikoloji yazınına kazandırılması, DİH'in Türk kültürü bağlamında farklı açılardan ele alınarak ve daha önce incelenmemiş ilişki örüntüleri araştırılarak hem Türk hem de dünya psikoloji yazınına önemli katkılar sağlayacaktır. Bu anlamda gelecek yıllarda DİH çalışmalarının niteliksel ve niceliksel olarak ivme kazanması beklenebilir. Hem bireysel hem de ilişkisel birçok psikolojik mekanizmada etkin rol oynaması nedeniyle DİH'in bireysel ve sosyal iyi oluşunla ilgili kritik bir kişilik özelliği olduğu dikkate alınmalıdır. Bu bağlamda DİH'in tüm yönleriyle sistematik bir şekilde incelenmesi bireysel ve sosyal gelişimin yetişkin mizacına ilişkin yönlerini anlamada önemli bir katkı sağlayacaktır.

\section{Kaynaklar}

Acevedo, B. P., Aron, E. N., Aron, A., Sangster, M. D., Collins, N. \& Brown L. L. (2014). The highly sensitive brain: an fMRI study of sensory processing sensitivity and response to others' emotions. Brain and Behavior, 4(4), 580-94.

Ahadi, B., \& Basharpoor, S. (2010). Relationship between sensory-processing sensitivity, personality dimensions, and mental health. Journal of Applied Sciences, 10, 570-574.

Ahadi, S. A., Rothbart, M. K., \& Ye, R. (1993). Children's temperament in the US and China: Similarities and differences. European Journal of Personality, 7(5), 359-378.

Aron, E., \& Aron, A. (1997). Sensory-processing sensitivity and its relation to introversion and emotionality. Journal of Personality and Social Psychology, 73(2), 345-368. 
Aron, E. N. (2004). Revisiting Jung's concept of innate sensitiveness. Journal of Analytical Psychology, 49, 337-367.

Aron, E. N., Aron, A., \& Davies, K. (2005). Adult shyness: The interaction of temperamental sensitivity and an adverse childhood environment. Personality and Social Psychology Bulletin, 31(2), 181-197.

Aron, A., Ketay, S., Hedden, T., Aron, E., Markus, H. R., \& Gabrieli, J. D. E. (2010). Temperament trait of sensory processing sensitivity moderates cultural differences in neural response [Special Issue on Cultural Neuroscience]. Social Cognitive and Affective Neuroscience, 5, 219-226.

Aron, E. N. (2011). Psychotherapy and the highly sensitive person: Improving outcomes for that minority of people who are the majority of clients. Routledge.

Aron, E. N., Aron, A., \& Jagiellowicz, J. (2012). Sensory processing sensitivity: A review in the light of the evolution of biological responsivity. Personality and Social Psychology Review, 16(3), 262-282.

Bakermans-Kranenburg, M. J., \& van IJzendoorn, M. H. (2006). Gene-environment interaction of the dopamine D4 receptor (DRD4) and observed maternal insensitivity predicting externalizing behavior in preschoolers. Developmental Psychobiology, 48(5), 406-409.

Bakermans-Kranenburg, M. J., \& van IJzendoorn, M. H. (2007). Research Review: Genetic vulnerability or differential susceptibility in child development: the case of attachment. Journal of Child Psychology and Psychiatry and Allied Disciplines, 48(12), 1160-1173.

Bakker, K., \& Moulding, R. (2012). Sensory-Processing Sensitivity, dispositional mindfulness and negative psychological symptoms. Personality and Individual Differences, 53(3), 341-346.

Belsky, J. (1997). Theory testing, effect-size evaluation, and differential susceptibility to rearing influence: The case of mothering and attachment. Child Development, 68(4), 598-600.

Belsky, J. (2005). Differential susceptibility to rearing influences: An evolutionary hypothesis and some evidence. In B. Ellis \& D. Bjorklund (Eds.), Origins of the social mind: Evolutionary psychology and child development (pp. 139-163). New York, NY: Guildford.

Belsky, J., Bakermans-Kranenburg, M. J., \& van IJzendoorn, M. H. (2007). For better and for worse: Differential susceptibility to environmental influences. Current Directions in Psychological Science, 16(6), 300-304.

Belsky, J. \& Pluess, M. (2009). Beyond Diathesis Stress: Differential Susceptibility to Environmental Influ- ences. Psychological Bulletin, 135(6), 885-908.

Benham, G. (2006). The highly sensitive person: Stress and physical symptom reports. Personality and Individual Differences, 40, 1433-1440.

Bradley, R. H., \& Corwyn, R. F. (2008). Infant temperament, parenting, and externalizing behavior in first grade: A test of the differential susceptibility hypothesis. Journal of Child Psychology and Psychiatry and Allied Disciplines, 49(2), 124-131.

Brindle, K., Moulding, R., Bakker, K., \& Nedeljkovic, M. (2015). Is the relationship between sensory-processing sensitivity and negative affect mediated by emotional regulation?. Australian Journal of Psychology, 67(4), 214-221.

Brown, C., Tollefson, N., Dunn, W., Cromwell, R., \& Filion, D. (2001). The adult sensory profile: Measuring patterns of sensory processing. American Journal of Occupational Therapy, 55(1), 75-82.

Booth, C., Standage, H., \& Fox, E. (2015). Sensory-processing sensitivity moderates the association between childhood experiences and adult life satisfaction. Personality and Individual Differences, 87, 24-29.

Borries, F. (2012). Do 'The Highly Sensitive' Exist?-A Taxometric Investigation of The Personality Construct Sensory-Processing Sensitivity. University of Bielefeld, Germany.

Chapman, B. P., Duberstein, P. R., Sörensen, S., \& Lyness, J. M. (2006). Personality and perceived health in older adults: the five factor model in primary care. The Journals of Gerontology Series B: Psychological Sciences and Social Sciences, 61, 362-365.

Cheek, J. M., \& Buss, A.H. (1981). Shyness and sociability. Journal of Personality and Social Psychology, 41(2), 330-339.

Chen, C., Chen, C., Moyzis, R., Stern, H., He, Q., Li, H., \& Dong, Q. (2011). Contributions of dopamine-related genes and environmental factors to highly sensitive personality: A multi-step neuronal system-level approach. PLoS ONE, 6, e21636.

Chen, X., Rubin, K. H., \& Sun, Y. (1992). Social reputation and peer relationships in Chinese and Canadian children: A cross-cultural study. Child Development, 63(6), 1336-1343.

Chen, C., Xiu, D., Chen, C., Moyzis, R., Xia, M., He, Y., ... \& Wang, Y. (2015). Regional Homogeneity of Resting-State Brain Activity Suppresses the Effect of Dopamine-Related Genes on Sensory Processing Sensitivity. PloS one, 10(8), e 0133143.

Dick, D. M. (2011). Gene-environment interaction in psychological traits and disorders. Annual Review of Clinical Psychology, 7, 383-409. 
Duberstein, P. R., Sörensen, S., Lyness, J. M., King, D. A., Conwell, Y., Seidlitz, L., \& Caine, E. D. (2003). Personality is associated with perceived health and functional status in older primary care patients. $P s-$ ychology and Aging, 18(1), 25-37.

Dunn, W. (1997). The impact of sensory processing abilities on the daily lives of young children and families: A conceptual model. Infants and Young Children, 9(4), 23-25.

Dunn, W. (2001). "The sensations of everyday life: empirical, theoretical, and pragmatic considerations." The American Journal of Occupational Therapy, 55(6), 608-620.

Evans, D. E., \& Rothbart, M. K. (2008). Temperamental sensitivity: Two constructs or one? Personality and Individual Differences, 44, 108-118.

Evers, A., Rasche, J., \& Schabracq, M. J. (2008). High sensory processing sensitivity at work. International Journal of Stress Management, 15, 189-198.

Eysenck, H. J. (1967). The biological basis of personality. Springfield, C. C. Thomas.

Eysenck, H. J. (1991). Biological dimensions of personality. In L. A. Pervin (Ed.), Handbook of personality (pp. 244-276). New York: Guilford Press.

Gearhart, C. C. (2014). Sensory-processing sensitivity and nonverbal decoding: The effect on listening ability and accuracy. International Journal of Listening, 28(2), 98-111.

Gearhart, C. C., \& Bodie, G. D. (2012). Sensory-processing sensitivity and communication apprehension: Dual influences on self-reported stress in a college student sample. Communication Reports, 25(1), 27-39.

Gerstenberg, F. X. (2012). Sensory-processing sensitivity predicts performance on a visual search task followed by an increase in perceived stress. Personality and Individual Differences, 53(4), 496-500.

Goodwin, R., \& Engstrom, G. (2002). Personality and the perception of health in the general population. Psychological Medicine, 32(2), 325-332.

Gray, J. A. (1981). A critique of Eysenck's theory of personality. In H.J. Eysenck (Ed.), Model for personality (pp. 246-276). New York: Springer.

Gray, J. A. (1990). Brain systems that mediate both emotion and cognition. Special Issue: Development of relationships between emotion and cognition. Cognition and Emotion, 4(3), 269-288.

Gray, J. A. (1991). The neuropsychology of temperament. In J. Strelau \& A. Angleitner (Eds.), Explorations in temperament (pp. 105-128). New York, NY: Plenum.

Grimen, H. L., \& Diseth, Å. (2016). Sensory Processing Sensitivity Factors of the Highly Sensitive Person
Scale and Their relationships to Personality and Subjective Health Complaints. Perceptual and Motor Skills, 123(3), 637-653.

Groves, P. M., \& Thompson, R. F. (1970). Habituation: A dual-process theory. Psychological Review, 77, 419-450.

Heinze, J. E., Kruger, D. J., Reischl, T. M., Cupal, S., \& Zimmerman, M. A. (2015). Relationships among disease, social support, and perceived health: A lifespan approach. American Journal of Community Psychology, 56(3-4), 268-279.

Hofmann, S. G., \& Bitran, S. (2007). Sensory-processing sensitivity in social anxiety disorder: Relationship to harm avoidance and diagnostic subtypes. Journal of Anxiety Disorders, 21(7), 944-954.

Homberg, J. R., Schubert, D., Asan, E., \& Aron, E. N. (2016). Sensory processing sensitivity and serotonin gene variance: Insights into mechanisms shaping environmental sensitivity. Neuroscience \& Biobehavioral Reviews, 71, 472-483.

Irwin, H. J., Schofield, M. B., \& Baker, I. S. (2014). Dissociative Tendencies, Sensory-Processing Sensitivity And Aberrant Salience As Predictors Of Anomalous Experiences And Paranormal Attributions. Journal of the Society for Psychical Research, 78(917), 193-206.

Jagiellowicz, J., Xu, X., Aron, A., Aron, E., Cao, G., Feng, T., \& Weng, X. (2011). Sensory processing sensitivity and neural responses to changes in visual scenes. Social Cognitive and Affective Neuroscience, 6(1), 38-47.

Jagiellowicz, J., Aron, A., \& Aron, E. N. (2016). Relationship between the temperament trait of sensory processing sensitivity and emotional reactivity. Social Behavior and Personality: An International Journal, 44(2), 185-199.

Johnson, S. L., Turner, R. J., \& Iwata, N. (2003). BIS/ BAS levels and psychiatric disorder: An epidemiological study. Journal of Psychopathology and Behavioral Assessment, 25(1), 25-36.

Jonsson, K., Grim, K., \& Kjellgren, A. (2014). Do highly sensitive persons experience more nonordinary states of consciousness during sensory isolation? Social Behavior and Personality: An International Journal, 42(9), 1495-1506.

Kagan, J. (1994). Galen's prophecy: Temperament in human nature. New York, NY: Basic Books.

Keltikangas-Jarvinen, L., Puttonen, S., Kivimaki, M., Elovainio, M., Rontu, R., \& Lehtimaki, T. (2007). Tryptophan hydroxylase 1 gene haplotypes modify the effect of a hostile childhood environment on adulthood harm avoidance. Genes, Brain, and Behavior, 6(4), 305-313. 
Kemler, D. S. (2006). Sensitivity to sensoriprocessing, self-discrepancy, and emotional reactivity of collegiate athletes. Perceptual and Motor Skills, 102(3), 747-759.

Kim-Cohen, J., Caspi, A., Taylor, A., Williams, B., Newcombe, R., Craig, I. W., \& Moffitt, T. E. (2006). MAOA, maltreatment, and gene-environment interaction predicting children's mental health: New evidence and a meta-analysis. Molecular Psychiatry, 11, 903-913.

Kjellgren, A., Lindahl, A., \& Norlander, T. (2009). Altered States of Consciousness and Mystical Experiences during Sensory Isolation in Flotation Tank: Is the Highly Sensitive Personality Variable of Importance? Imagination, Cognition and Personality, 29(2), 135-146.

Kochanska, G., Aksan, N., \& Joy, M. E. (2007). Children's fearfulness as a moderator of parenting in early socialization: Two longitudinal studies. Developmental Psychology, 43(1), 222-237.

Licht, C., E. L. Mortensen, \& G. M. Knudsen. (2011) Association between sensory processing sensitivity and the serotonin transporter polymorphism 5-HTTLPR short/short genotype. Biological Psychiatry, 69, 152-153.

Liss, M., Timmel, L., Baxley, K., \& Killingsworth, P. (2005). Sensory processing sensitivity and its relation to parental bonding, anxiety, and depression. Personality and Individual Differences, 39, 14291439.

Liss, M., Mailloux, J., \& Erchull, M. J. (2008). The relationship between sensory processing sensitivity, alexithymia, autism, depression, and anxiety. Personality and Individual Differences, 45, 255-259.

Markus, H. R., \& Kitayama, S. (1991). Culture and the self: Implications for cognition, emotion, and motivation. Psychological Review, 98(2), 224-253.

McCrae, R. R., Zonderman, A. B., Costa Jr, P. T., Bond, M. H., \& Paunonen, S. V. (1996). Evaluating replicability of factors in the Revised NEO Personality Inventory: Confirmatory factor analysis versus Procrustes rotation. Journal of Personality and Social Psychology, 70(3), 552-566.

Mendaglio, S., 2003. Heightened multifaceted sensitivity of gifted students. Journal of Secondary Gifted Education, 14(2), 72-82.

Meredith, P. J., Bailey, K. J., Strong, J., \& Rappel, G. (2016). Adult Attachment, Sensory Processing, and Distress in Healthy Adults. American Journal of Occupational Therapy, 70(1), 1-8.

Meyer, B., Ajchenbrenner, M., \& Bowles, D. P. (2005). Sensory sensitivity, attachment experiences, and rejection responses among adults with borderline and avoidant features. Journal of Personality Disorders, 19(6), 641-658.

Meyer, B., \& Carver, C. S. (2000). Negative childhood accounts, sensitivity, and pessimism: A study of avoidant personality disorder features in college students. Journal of Personality Disorders, 14(3), 233-248.

Monroe, S. M., \& Simons, A. D. (1991). Diathesis-stress theories in the context of life stress research: Implications for the depressive disorders. Psychological Bulletin, 110(3), 406-425.

Neal, J. A., Edelmann, R. J., \& Glachan, M. (2002). Behavioral inhibition and symptom anxiety and depression: Is there a specific relationship with social phobia? British Journal of Clinical Psychology, 41(4), 361-374.

Obradovi'c, J., Bush, N. R., Stamperdahl, J., Adler, N. E. \& Boyce, W. T. (2010). Biological Sensitivity to Context: The Interactive Effects of Stress Reactivity and Family Adversity on Socioemotional Behavior and School Readiness. Child Development, 81(1), 270-289.

Pluess, M., Belsky, J., Way, B. M., \& Taylor, S. E. (2010). 5-HTTLPR moderates effects of life events on neuroticism: Differential susceptibility to environmental influences. Progress in Neuro-Psychopharmacology \& Biological Psychiatry, 34(6), 1070-1074.

Pluess, M. \& Belsky, J. (2012). Vantage Sensitivity: Individual Differences in Response to Positive Experiences. Psychological Bulletin, 139(4), 901-916.

Pluess, M., \& Boniwell, I. (2015). Sensory-processing sensitivity predicts treatment response to a school-based depression prevention program: Evidence of vantage sensitivity. Personality and Individual Differences, 82, 40-45.

Rizzo-Sierra, C. V., Leon-S, M. E., \& Leon-Sarmiento, F. E. (2012). Higher sensory processing sensitivity, introversion and ectomorphism: New biomarkers for human creativity in developing rural areas. Journal of Neurosciences in Rural Practice, 3(2), 159-162.

Rothbart, M. K., \& Jones, L. B. (1999). Temperament: Developmental perspectives. In R. Gallimore, L. Bernheimer, \& T. Weisner (Eds.), Developmental perspectives on children with high-incidence disabilities. The LEA series on special education and disability (pp. 33-53). Mahwah, NJ: Erlbaum.

Sameroff, A. J. (1983). Developmental systems: Contexts and evolution. In P. Mussen (Ed.), Handbook of child psychology (Vol. 1, pp. 237-294). New York, NY: Wiley. 
Smolewska, K. A., McCabe, S. B., \& Woody, E. Z. (2006). A psychometric evaluation of the Highly Sensitive Person: The components of sensory-processing sensitivity and their relation to the BIS/ BAS and "Big Five". Personality and Individual Differences, 40, 1269-1279.

Sobocko, K., \& Zelenski, J. M. (2015). Trait sensory-processing sensitivity and subjective well-being: Distinctive associations for different aspects of sensitivity. Personality and Individual Differences, 83, 44-49.

Strelau, J. (1983). Temperament, personality, activity. San Diego, CA: Academic Press.

Strelau, J., \& Zawadzki, B. (1993). The Formal Characteristics of Behaviour-Temperament Inventory (FCB-TI): theoretical assumptions and scale construction. European Journal of Personality, 7(5), 313-336.

Şengül-İnal, G. (2014). The moderating role of sensory-processing sensitivity in the relationship between spousal caregiving, perceived social support and marital quality. Unpublished Master's thesis, Middle East Technical University, Ankara, Turkey.

Şengul-İnal, G. \& Sümer, N. (2016). The relation between gender role orientations and environmental sensitivity traits. Paper presented at 1st Congress of Social Psychology, Başkent University, Ankara.

Şengül-İnal, G. \& Sümer, N. (2017). Exploring the multidimensional structure of sensory processing sensitivity in Turkish Samples. Current Psychology, doi:10.1007/s12144-017-9751-0.

Şengül-İnal, G., Kırımer-Aydınlı, F. \& Sümer, N. (2018). The role of attachment insecurity and big five traits on sensory processing sensitivity. Journal of Psychology: Interdisciplinary and Applied, 152(7), 497-514.
Taylor, S. E., Way, B. M., Welch, W. T., Hilmert, C. J., Lehman, B. J., \& Eisenberger, N. I. (2006). Early family environment, current adversity, the serotonin transporter promoter polymorphism, and depressive symptomatology. Biological Psychiatry, 60, 671-676.

Thomas, A., \& Chess, S. (1977). Temperament and development. New York: Brunner/Mazel.

Thompson, R. E, \& Spencer, W. A. (1966). Habituation: A model phenomenon for the study of neuronal substrates of behavior. Psychological Review, 73(1), 16-43.

Uljarević, M., Carrington, S., \& Leekam, S. (2016). Brief Report: Effects of sensory sensitivity and intolerance of uncertainty on anxiety in mothers of children with Autism Spectrum Disorder. Journal of Autism and Developmental Disorders, 46(1), 315-319.

Wachs, T. D. (2013). Relation of maternal personality to perceptions of environmental chaos in the home. Journal of Environmental Psychology, 34, 1-9.

Widiger, T. A. (2009). Neuroticism. In Leary, M. R., \& Hoyle, R. H. (Eds.). Handbook of individual differences in social behavior (pp. 129-146). Guilford Press.

Wilson, D. S., Clark, A. B., Coleman, K., \& Dearstyne, T. (1994). Shyness and boldness in humans and other animals. Trends in Ecology \& Evolution, 9(11), 442-446. 


\section{Summary Sensory Processing Sensitivity: Theoretical Framework and Literature Review}

\author{
Gülbin Şengül-İnal \\ Middle East Technical University
}

This paper systematically reviews the previous studies addressing sensory processing sensitivity (SPS). People perceive and interpret stimuli in their social and physical environment and show appropriate (compatible) responses to these stimuli. However, those who experience deep sensory processing strategies differ significantly in perceiving, interpreting and responding to the sensory information in the environment. Sensory processing sensitivity, which was coined by Aron and Aron (1997), defines this fundamental difference in experiencing and expressing sensory information as well as employing different sensory processing strategies. Considering that there is a shortage of studies on SPS in the Turkish psychology, we aimed to first introduce this increasingly investigated concept with its theoretical framework to the Turkish researchers, and then, systematically review the main findings in this area.

\section{Description of Sensory Processing Sensitivity}

SPS (Aron \& Aron, 1997) is an inherent temperamental trait which is characterized by deep cognitive processing of physical (i.e., noise, light) as well as emotional (i.e., other people's moods and emotions) stimuli (Aron, Aron \& Jagiellowicz, 2012). Highly sensitive people recognize subtle details and changes more quickly, are easily overwhelmed by strong stimulations (e.g., bright lights, strong smell, loud noise), and show heightened emotional reactivity towards positive and negative situations (Aron \& Aron, 1997; Aron et al., 2012). There are four basic features that distinguish SPS from other temperament traits (Aron, 2011; Aron et al., 2012); (1) deep sensory processing, (2) behavioral inhibition, (3) overstimulation, and (4) emotional/physiological reactivity.

The theoretical framework of SPS has been established within the personality research from an evolutionary perspective. Animals have developed specific temperament traits to keep up with nature and to survive in harsh conditions. These temperament traits are shaped

\author{
Nebi Sümer \\ Sabancı University
}

by the joint effect of environmental conditions and survival strategies. For example, while some animal species in threatening and novel situations tend to be highly cautious and vigilant for potential dangers and novelty, others in safe environments can be bold and unresponsive (Wilson, Coleman, Clark \& Biederman, 1993). Aron et al. (2012) hypothesized that similar variations are also observed in humans and best described by the SPS trait.

\section{Characteristics of Highly Sensitive People}

Since highly sensitive people have low sensory threshold, they perceive and process information faster than those with low sensitivity. Highly sensitive people pause and then process information deeply before getting into an action so as to prevent potential danger and negativity. This is called typical "pause to check" type of behavior (Aron \& Aron, 1997; Aron et al., 2012). This is why highly sensitive people who have a deep and complex inner life than those with low sensitivity are delighted by fine arts and music (Aron, 2004; Aron \& Aron, 1997)

\section{Measurement of Sensory-Processing Sensitivity}

Aron and Aron (1997) developed a 27-item "The Highly Sensitive Person Scale" (HSPS) for the measurement of the SPS in six subsequent studies. Scale items cover various sensory sensitivity indicators such as being overwhelmed by strong stimulations such as noise, and bright light, easy startle, overstimulation during multitasking, and being delighted by aesthetic values. The researchers using the HSPS found that the scale had a one-factor structure (Hofmann \& Bitran, 2007; Neal, Edelmann \& Glachan, 2002). However, subsequent studies found an evidence for two (Evans \& Rothbart, 2008), three (Smolewska et al., 2006), and four (Meyer, Ajchenbrenner \& Bowles, 2005; Şengül-İnal \& Sümer, 2017) factorial structure for the scale.

Address for Correspondence: Res. Asst. Gülbin Şengül-İnal, Middle East Technical University, Department of Psychology, Üniversiteler Mah. Dumlupınar Blv. No:1, 06800, Ankara

E-mail: gulbinsengul@gmail.com 


\section{Empirical Research on SPS}

Studies on SPS were reviewed in Web of Science, PsycARTICLES, PsycINFO and EBSCOhost databases by using following keywords; (1) 'sensory processing sensitivity', (2) 'sensory sensitivity', and (3) 'highly sensitive people'. The results obtained were elaborated under six broad headings; (1) personality trait findings, (2) negative psychological findings, (3) psychological well-being findings, (4) neuroscience and genetic findings, (5) trait-environment interaction findings, and (6) other findings on SPS.

\section{Personality Trait Findings}

The research findings showed that SPS is systematically and moderately strongly associated with neuroticism, introversion, and openness (Ahadi \& Basharpoor, 2010; Grimen \& Diseth, 2016; Licht, Mortensen \& Knudsen, 2011; Smolewska et al., 2006; Sobocko \& Zelenski, 2015; Şengül-İnal, Kırımer-Aydınlı \& Sümer, 2018) and harm avoidance (Hofmann \& Bitran, 2007; Licht et al., 2011). Moreover, the findings indicated that there is a strong relationship of SPS with behavioral inhibition sensitivity, but a weak one with behavioral activation (Smolewska et al., 2006; Sobocko \& Zelenski, 2015).

\section{SPS and Negative Psychological Outcomes}

A number of studies have found a significant relationship between SPS and high levels of stress and anxiety (Ahadi \& Basharpoor, 2010; Bakker \& Moulding, 2012; Gearhart \& Bodie, 2012; Kjellgren, Lindahl \& Norlander, 2009; Liss, Timmel, Baxley \& Killingsworth, 2005; Meredith, Bailey, Strong \& Rappel, 2016). SPS was also positively associated with rejection anxiety (Meyer et al., 2005) and attachment anxiety (Meredith et al., 2016; Şengül-İnal et al., in press).

\section{SPS and Psychological Adjustment}

SPS has been closely associated with agoraphobia, which is defined as a fear of being in closed and crowded places (Meyer \& Carver, 2000; Neal et al., 2002), avoidant and borderline personality disorder (Meyer et al., 2005), social functioning disorder (Ahadi and Basharpoor, 2010) and depression (Liss et al., 2005; Liss et al., 2008; Bakker and Moulding, 2012; Brindle et al., 2015; Meyer et al., 2005; Ahadi and Basharpoor, 2010). Apart from current psychological well-being symptoms, high sensitivity was also related to higher scores on perceived ill-health report (Benham, 2006).

\section{Neuroscience and Genetic Findings}

Because SPS is an inborn characteristic like other personality and temperamental traits, researchers are interested in investigating its biological underpinnings. The evidence obtained from functional magnetic resonance imaging (fMRI) studies showed that highly sensitive individuals are more attentive to subtle sensory stimuli during the performance of visual-detection task (Aron et al., 2010) and less likely to be affected by the culturally relevant contexts (Jagiellowicz et al., 2011). Highly sensitive people show more neural responses in the brain regions responsible from sensorimotor activities when exposed to subtle and self-referential emotional stimuli (e.g., Acevedo et al., 2014). Furthermore, Chen and his colleagues (2015) found that these brain regions are more active even when the person is deprived of any cognitive load. Genetic studies, on the other hand, suggested that SPS is related to serotonin (Licht et al., 2011) and dopamine-related genes (Chen et al., 2011). Overall, reviewed studies have demonstrated that SPS has a strong link with specific neural responses and genes that evidently distinguish highly sensitive and non-highly sensitive individuals.

\section{Trait-Environment Interaction Findings}

Studies on gene/trait-environment interaction suggest that some individuals are genetically more sensitive or developmentally more responsive and flexible to negative and positive environmental effects as a function of their specific genetic makeup. Gene-environment interaction studies have introduced three basic approaches to explain human developmental plasticity: Diathesis-Stress Model (Monroe \& Simons, 1991) which represents biological vulnerability to adverse environmental effects, Differential Susceptibility Hypothesis which represents individual responsivity to both positive and negative environmental effects (Belsky \& Pluess, 2009), and Vantage Sensitivity (Pluess \& Belsky, 2012) which refers to exclusive responsivity to positive experiences.

Given that highly sensitive people have specific genetic variant (i.e. 5-HTTPLR and DRD2) influencing human plasticity, studies have provided empirical evidence on how SPS supports gene-environment interaction. For example, Aron, Aron and Davies (2005) investigated the interplay between SPS and environmental factors in four subsequent studies and found that highly sensitive individuals with negative childhood history reported more shyness than those with low sensitivity. Pluess and Boniwell (2015) investigated the SPS trait as a plasticity marker for economically disadvantageous school girls, and found that those with high sensitivity benefit more from school intervention program by displaying lower level of depression than those with low sensitivity. These findings suggest that SPS is an important personality trait that supports the notion of gene-environment interaction (see Homberg, Schubert, Asan and Aron, 2016). 


\section{Other Findings}

This section aims to present the findings of studies, in which SPS was found to have a potential for influencing different life domains, such as work, home, sociality, and spirituality. Extant studies showed that SPS is related to work alienation, and work stress, and lack of sense of cohesion (Evers et al., 2008). Concerning the home context, Wachs (2013) investigated whether SPS moderated the relationship between the actual and perceived home chaos by mothers, and found that mothers with high sensitivity perceived home organization as more chaotic than those with low sensitivity. With regard to communication skills, Gearhart and Bodie (2012) found that a higher score on the sensitivity trait was associated with greater communication apprehension. Researchers also investigated the link between SPS and spiritual experiences, and found a positive association between SPS and parapsychological experiences such as altered state of conscientiousness and mystical states (e.g., Irwin, Schofield \& Baker, 2014; Jonsson, Grim \& Kjellgren, 2014; Kjellgren, Lindahl \& Norlander, 2009).

\section{General Discussion and Suggestions}

The aim of this article was to review empirical studies on SPS, and to introduce the main findings to Turkish researchers. The major empirical findings of the SPS were reviewed, classified, and summarized under six sub headings.

Given the summarized research findings, it appears that SPS is mainly associated with negative vari- ables such as anxiety, stress, or psychological disorder symptoms. It was speculated that negative psychological outcomes such as anxiety and stress may indeed be functional for highly sensitive people and serve as an early alarm system by constantly keeping them alert and protecting them from the potential emotional negativity and environmental adversity. Lack of empirical studies on the advantages of SPS is noteworthy. Aron (2004) and Zeff (2015) point out that SPS has many advantages such as the fact that highly sensitive people are more creative than non-sensitive people, have more advanced sense and emotional perception skills, better ability to empathize and a higher sense of responsibility and conscientiousness.

It was concluded that the SPS literature is limited on two important points. The first limitation is that SPS has not been examined in cross-cultural comparative studies. The second limitation is that SPS has not been examined in the context of close relationship dynamics. The research on the factor structure of HSPS showed that there are inconsistent findings on its factor structure. Different factorial structures of the scale make it difficult to compare the study findings and make consistent inferences.

Overall, this paper has contributed to Turkish psychology literature by providing in-depth and up-to-date review on the SPS trait. Future researchers should examine the dynamics of SPS in the Turkish culture and further explore its functionality in both intraindividual and interindividual processes. 